Old Dominion University

ODU Digital Commons

English Theses \& Dissertations

English

Spring 2017

\title{
Unconditional Positive Regard
}

Tyler Beckett

Old Dominion University, tbeck015@odu.edu

Follow this and additional works at: https://digitalcommons.odu.edu/english_etds

Part of the Creative Writing Commons

\section{Recommended Citation}

Beckett, Tyler. "Unconditional Positive Regard" (2017). Master of Fine Arts (MFA), Thesis, English, Old Dominion University, DOI: 10.25777/z91c-bn23

https://digitalcommons.odu.edu/english_etds/26

This Thesis is brought to you for free and open access by the English at ODU Digital Commons. It has been accepted for inclusion in English Theses \& Dissertations by an authorized administrator of ODU Digital Commons. For more information, please contact digitalcommons@odu.edu. 


\section{UNCONDITIONAL POSITIVE REGARD}

by

Tyler Beckett

B.A. May 2014, Lee University

A Thesis Submitted to the Faculty of Old Dominion University in Partial Fulfillment of the

Requirements for the Degree of

MASTER OF FINE ARTS

CREATIVE WRITING

OLD DOMINION UNIVERSITY

May 2017

Approved by:

John McManus (Director)

Janet Peery (Member)

Michael Pearson (Member) 


\section{ABSTRACT \\ UNCONDITIONAL POSITIVE REGARD}

Tyler Beckett

Old Dominion University, 2017

Director: Prof. John McManus

"Unconditional Positive Regard" collects the work of Tyler Beckett for the first time, presenting his exploration of community and belonging in the American south. The title of this collection represents one of the guiding principles of the work: the author must have faith in his characters, regardless of motive, background, identity, or failings, and he must believe that they are trying to do what is right. Here you will read about grandmothers, community workers, Boy Scouts, and demons as they explore the festivals, drum circles, and towns that govern their lives. Whether they are thankful for that relationship or resent it, the characters and stories within strive for a goodness that feels authentic in the place they are in. 


\section{TABLE OF CONTENTS}

\section{Page}

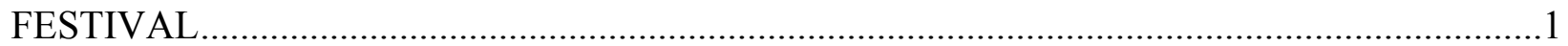

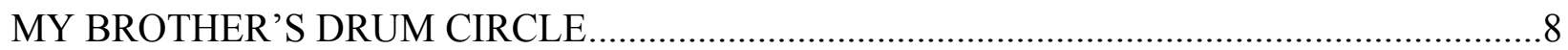

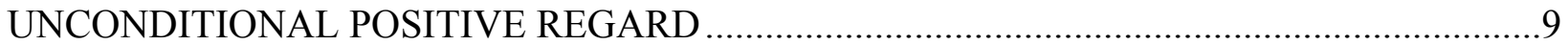

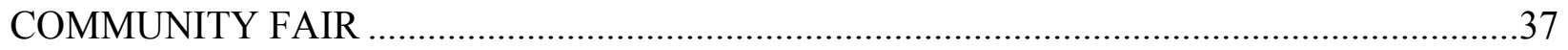

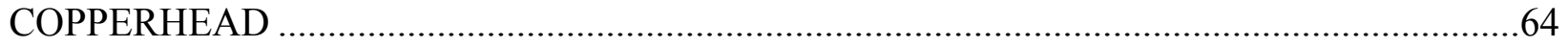

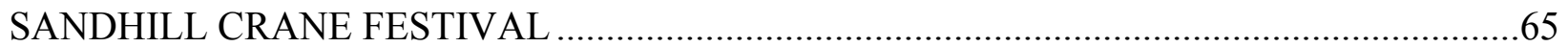

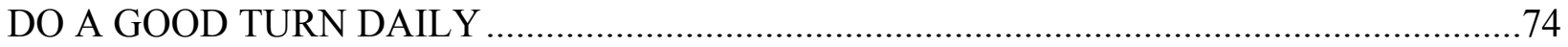

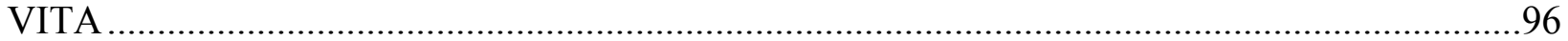




\section{FESTIVAL}

Ryan liked to feel certain that he had an apparent purpose - that is, a reason obvious to any outside observer - wherever he went, which is why he found it so uncomfortable to sit alone with a teddy bear in the middle of the Peach City festival. He was worried he looked like a creep, like his grungy t-shirt and the hair hanging in his eyes inched him closer towards ne'er-do-well rather than the bewildered boyfriend-look he had accepted upon entrance. He liked that role; Audrey leading him by the arm, pointing and explaining her hometown's traditions while he looked wide-eyed, a boy from the city amazed to see what passed for a festival in rural Georgia. Fried oreos? Fried kudzu? He'd said it all with delighted incredulity, savoring Audrey's childish excitement. She had shoved two of the oreos in her mouth, as if a declaration of Yes, this IS where I come from! It was lovely. Ryan wanted to fit in in this place, in this world that was hers; he won the ring toss and got her the teddy bear like it was a claim at belonging. He wished she had left a purse with him, so he could still appear claimed.

A cluster of children moved down the line of stalls, running in and out of the booths and annoying the local artists and honey bottlers. Ryan did his best to appear completely uninterested, like he was saying, Children? Yuck. Who would even want to look at a child? Not me. I'm definitely not a guy waiting to give a child a teddy bear, no sir.

Part of the problem was that Audrey didn't carry purses, so he found himself wishing her friend Katelyn had left hers. Large, leather, and monogrammed, it was like the woman's entire identity was implied in the bag. Why yes, she had grown up in the South. And yes, she had joined that sorority and married that lawyer. It was so effective a symbol that it erased the history of free-or-reduced school lunches and summer jobs at blueberry farms with Audrey. It 
was such a clear rejection of the life Audrey had described, of the town he discovered.

A man stopped beside Ryan's seat at the picnic table. "Can I help you?" he said. He was a tall guy, though easily in his sixties, with a gut that stretched his flannel shirt and ended abruptly at the waist of his jeans. He looked like he belonged here.

"No, I'm fine," Ryan said, then added, "Sir. Just waiting for my girlfriend and her friend."

The man nodded once. "Who's your girlfriend?"

What was this, some kind of test? Ryan felt himself bristle, but he forced himself to act self-assured. Belonging, he figured, is half confidence. "Audrey Logan. She grew up around here."

"Don't know any Logans."

"She grew up by Walker's Creek. With the covered bridge?"

"Hm," the man said. He looked into the sun, scratched his beard. "You wanna join us for a round of horseshoes?"

Somehow, Ryan said yes. The suddenness of Moe's invitation - "Name's Moe, by the way" - was such that he could not reasonably reject it. So he met the guys: Moe, Bennett, Trey, all of whom carried horseshoes like that wasn't an anachronism, some out-of-place prop in a school play. But they were real, and they were rusted, and the fact that Ryan had never held one stood out to all his new friends.

"Now listen here, Ryan, I'm gonna help you make this work," Trey said. "It's an acquired touch, but I'll teach you right."

“Sure you will,” Bennett said. “And who'll teach you?” Moe nodded, smiled. Ryan tried to imitate the good-natured smile, but he thought Trey just looked offended. 
"No need for a peanut gallery. Now Ryan, you hold it, just so, underhand you see, and stand to the left. Move your arm like you would a bowling ball, a straight line, like this. Then let go on the upswing!"

Trey's horseshoe fell several feet off-target. Both Moe and Bennett let out big belly laughs.

"Well," Trey said, "Do as I say, not as I do."

Ryan thought of how he looked here, playing horseshoes with three, much older men. $\mathrm{He}$ probably looked like he was someone's adult son. All three of them could be his father, all of them the same shade of white and same masculine build. Maybe he was a mechanic nearby, or worked a register at the Publix. Audrey said that half her high school class stayed in town, which she made sound like a kind of indictment. Both she and Katelyn had made it out, she was proud to say. She had pointed out abandoned houses when they drove into town, the fields of grass where cracked streets and fading fire hydrants arranged themselves around houses that were never built. "Two-thousand and eight was real bad for us," was all she said.

But Ryan didn't want to believe all that about this town. How could she not love a town, he wondered, with a festival like this? There were so many vendors, so many pitmasters and families and petting zoos with lambs and kennels with puppies to adopt. You couldn't make a prettier, more welcoming scene.

Ryan waited until he had tossed his horseshoe to ask his question. "Moe, what is Peach City really like?"

Moe turned a horseshoe over in his hands, brushing dirt off of it and speaking as if the question was perfectly predictable. “When I was a boy, Peach City was all cotton. I don’t remember a time when it grew many peaches. But it's always been agriculture; my church now 
stands where the cropdusters would take off and land. And my grandfather was one of the folks who fought to keep the town from changing too much. She thought we owed it all to Cotton. So the south side of town stayed cotton, and the north side got better roads, got schools, got a bottling plant. Got a lot more people. Then the north side grew some more, got suburban. My mother didn't like that, so-"

"Jesus, Moe, he asked what's it like, not the history," Trey said. "Peach City is a good place, so long as we keep the highway away."

"And the wastewater treatment plant," Bennett said. "Can't have that."

“That's what I'm saying," Moe said. "Everyone wants Peach City to be exactly big enough for them, and no more."

Trey was huffy for a little while, especially when Bennett threw two ringers in a row. So Ryan made a show of buying all the guys iced tea from the Chick-fil-A stand, as thanks for their hospitality. They were much obliged. The four of them sat at a table together, and Bennett told them how good the fishing used to be around those parts. Ryan was delighted to be therepleased as a peach, he thought — even with the teddy bear on the bench beside him. Imagine trying to form this friendship with folks on the bus, Ryan thought, or the guys at the office. No way that would happen. But here he was one of the boys, swapping stories and slinging shoes, shooting the breeze and biding their time. How cool was this? How good was it to have immediate kinship?

"Ryan, finally!" Katelyn waved from the other side of the picnic area, her bracelets clattering. "Audrey and I have been looking all over for you!"

Ryan stood to introduce his new friends, but Moe was already on his feet. "Well if that doesn't beat it all. Katelyn Maher, finally back in town!" 
Katelyn placed her hand beneath her chin and batted her eyes prettily. "I could not stay away! Not when the men of Peach City are universally handsome!" She leaned over and pecked him on the cheek. "It's good to see you, Moe. Trey, Bennett."

"Hello there, Miss Maher."

"It's Wilson now," she corrected, and she showed the diamond-wrapped ring for which Ryan couldn't even imagine making a down payment.

“Isn't that something. I remember when she was Homecoming Queen, and now she's off and married. Is the lucky man here?”

"No," Katelyn said. "He couldn't make it today. I'm visiting with my old friend, Audrey Adams."

The men got quiet. Trey and Bennett exchanged glances. “'Adams'?” Moe asked Ryan, as if he was caught in a lie.

Ryan felt his face grow hot, though he didn't know what was going on. “Oh, her mom's maiden name. I should have said that instead of 'Logan,' then. Honest mistake.”

"Hardly worth calling it a mistake," Katelyn said. Something in the way she held herself now, the way she maintained eye contact the older men, seemed to dare them to contradict her. There was an invisible struggle going on, Ryan knew, but he couldn't guess what it was about. Moe broke first. "Well. We've kept Ryan long enough. Don’t forget your stuffed bear." The men shook hands with Ryan, and he tried to meet their polite smiles. The group didn't look like friends now, just professionals who had had a productive meeting and were eager now to get to lunch. They were formal, distant, disinterested. Ryan shook Moe's hand last.

"Sir, I had a really good time, and I appreciate the invitation. Thank you." Moe nodded to him one last time. "You seem like a good man. Make sure you're with a 
good woman."

Katelyn snatched Ryan away before he could say anything more. "Old jerks," she said to herself, her bag swinging from her arm like a wrecking ball gone wild. "Still holding on to twenty year-old drama."

"What was that all about?" Ryan asked. The way he was being tugged along he probably looked like a child being scolded by his mother; the teddy bear no doubt added to the affect. Maybe people would assume he was a layabout brother, the Maher black sheep.

Katelyn glanced at him over her shoulder. "I suppose Audrey wouldn’t want me to talk about it. Still, I thought by now_-" She didn't finish the thought, but Ryan understood. He'd dated Audrey for two years and this was the first time they'd made the half hour trip to her hometown.

"There's not that much to tell, anyways," Katelyn said. "Her mother had all sorts of trouble, being unwed and all. Town this size, well, that sort of thing follows you to school. It was waiting for her at church, too. Oh, Ryan, wait!" Katelyn pulled him aside and into the shade of a tent. She beamed at him now, Audrey’s history completely forgotten. “'Church!' I forgot why I was coming to get you in the first place. How do you feel about proposing this weekend?"

The question blind-sided him; the one time Ryan had even mentioned marriage to Audrey, she had told him to 'not be so basic.' Was Audrey expecting something out of him? "Where is this coming from?"

"Look, I found this gorgeous jeweller here, she has amazing gemstones," Katelyn said, and she singled out one of her bracelets. "See? Rose gold, and these are garnets. Only one-sixty, which is spectacular. And I thought, why not now? They have all kinds of rings if you're not into diamonds. I gave her a few things to try on while I went looking for you.” 
Katelyn pointed past the corner of the tent, and Ryan leaned his head out. There was the jeweller's booth, and inside was Audrey, wearing yoga pants and an old sweatshirt, wrapped in gold necklaces and jangling bracelets and pearl earrings that waggled free of her ponytail. He could never guess what people saw when they looked at her. Did they see the pragmatism he liked, the blunt ingenuous woman? Did they see a woman who looked a little sloppy, who didn't try hard enough? He could not say for sure. How was he so bad at seeing things as they were? And what did Moe, Bennett, Trey, even Katelyn see when he was with her?

In a moment he would go to her, and Ryan would ask Katelyn if she wanted to leave. He suspected she would say yes; he suspected she had had enough of Peach City by now. But for a moment, with Katelyn at his back and the great body of the festival surrounding him, Ryan tried to see Audrey as her hometown saw her. They would not see her radiant smile, nor her sharp wit; instead, the jewelry made her look like someone put their best Christmas decorations on a shrub. She looked like she had wandered into the wrong shop and refused to admit her mistake, like Pretty Woman but without the second, triumphant scene; the big mistake was hers. Or maybe the plant image was better, Ryan thought, because she looked like a seed that was planted in the wrong soil, or was choked by thorns, or was planted in the shade of trees that were glad to steal her sun. 


\section{MY BROTHER'S DRUM CIRCLE}

You drag me to the drum circle saying things like "this will change your life" with no mind of how stupid you sound. We drive to a park-turned-mosh pit, so far from quiet Peach City that the dancers who appear at dusk to fill the plaza could be from foreign planets. Pothead percussionists bang their pots, pans, park signs and sundry possessions while their shouted songs rattle my ears. People are topless, packed tight, bouncing and singing in a raucous ripple that we get lost in. You, the small-town refugee, the hick-turned-granola mountaineer, the hike guide who carries a tent for two just-in-case, you're having fun. Each time a woman rocks to-and-fro or two bros reach overhead to pass a blunt, you get sucked further in, and these gaps between torso and arm, quick as eighth rests, are enough to let you enter. And I, despite shouldering hippies aside, despite saying, "Sorry y'all, that's my brother up ahead," find myself repulsed, pushed to the edges, where tourists watch this ridiculous blowout and snap photos. And all I'm saying is, what the hell, you said we'd hang out. 


\section{UNCONDITIONAL POSITIVE REGARD}

Though it rankled some, though the isolation drove a few folks a little too insane, Sonneillon found the solitary life of a demon agreeable. She simply didn't enjoy the company of others, especially when 'others' were frequently dull and dimwitted. Recently Sonneillon had taken a trip down the Appalachian Trail, spooking night hikers by rattling leaves and sneaking bugs into their boots, but when she wasn't having her fun she would pick a boulder, take a seat, and watch shooting stars and space debris drifting in the night sky. That was in 1932; she didn't speak a word for almost ten months. Eighty-odd years later she was still trying to break that record.

Sonneillon made exceptions only for Mother Margaret, and usually under better circumstances than these. She sat in the Mother Superior's waiting room, invisible and fuming, watching the clock as her appointment time ticked closer. Only high-ranking clergy knew that the Church maintained a formal relationship with spirits, so Margaret had to wait until dinner when she was certain no one was around. That made all of this very inconvenient for Sonneillon. The magazines were old, the chair was uncomfortable, and a distraught Filipina nun sulked in the opposite corner. The woman didn't know she was there, but Sonneillon still found her presence aggravating. Margaret better not have double-booked herself, because there was no chance she'd let a nun take her place, no matter how melancholy or weepy she got.

The first indication of Margaret's approach was the thrum of guitar riffs in her office, a mix of prog and sludge metal that Sonneillon admired, driven by a strong rhythmic drumbeat. So she had opened the album already. Sonneillon smiled to herself and stood as Mother Margaret opened her door. 
"Sonneillon?” Margaret said. "I am ready to 'see' you now."

"That joke was old eight years ago, Margaret," Sonneillon said, still invisible. "Are you finally going senile, you wretched bird?"

“Oh, get in here. I've got a whole speech prepared on how metal isn't what it used to be." Mother Margaret led Sonneillon — and, oddly, the nun followed — into the office and sat behind her desk, an unattractive plastic behemoth with gum on its underside. Sonneillon knew there was gum on the bottom because she had immediately flown under the desk. It was an easy thing for a demon to do, to flit through and appraise a room, but for Sonneillon it was necessary to keep her anxiety — she liked to call it "anxiety," because the other, more clinical names sounded so dramatic — in check. Otherwise she'd be looking over her shoulder the whole time.

So Sonneillon organized the room, both to know its contents and to spend some of her nervous energy. There were dust bunnies and paper clips intermingled on the floor, which she sorted into two piles and left by Margaret's feet. Then the waste basket's contents had to be sorted, power cords needed plugged in, blinds needed dusting. As a final touch she straightened the chair the Filipina nun had chosen to sit in. She squeaked, but Margaret remained smiling. Whatever reason the nun had for joining them, Margaret must have approved.

Margaret turned down the new Anciients album Sonneillon had given her. For the first time, Sonneillon noticed tension about her shoulders. "I am glad you stopped by, Sonneillon; I have needed to talk to you about something for a few weeks now. But seeing as I am unable to contact you_-" she trailed off.

“Ah. Sorry about that," Sonneillon said mildly. She wasn't terribly sorry; Margaret may be her friend, but Sonneillon's privacy was precious to her. She checked in every few months, at least once a year, and was satisfied that no one could talk to her unless she wanted to. 
"Well, that's fine," Margaret said. "But I think you had something to discuss first?"

"Yes. Margaret, I fear the worst has happened. It's teenagers. They have an Ouija Board.”

Margaret smiled and put her chin in her hand. "Goodness."

"They have no right. Bothering an old demon, and what for? 'Will Tom Zerkel ask her to prom?"”

"I don’t know any Zerkels."

"It's not him, it's these girls. Bethany Carver and Sara Washington."

"Washington might be in our database. Let me check." Margaret turned to her computer.

Sonneillon paced the air, observing Margaret's face. Had she been crying? She pressed on while she tried to puzzle out what was wrong. "Furthermore, I resent the odd hours. Maybe nuns are supposed to be on call twenty-four seven, I wouldn't know, but the Ouija causes this terrible buzzing in my head when all I want is a peaceful evening to myself. You can see how that would be bothersome." Margaret looked sympathetic, while the Filipina nun looked wideeyed into the air. Her presence was increasingly grating.

"Did you retaliate in any way?" Mother Margaret asked.

"I keep holding the wooden planchette down on 'No.' Sara cried. She fancies him."

The nun spoke up. "Aggression, even mild aggression, is not a healthy response."

Sonneillon was surprised; she had expected the nun to keep quiet. "Any response is an unhealthy response, because talking to humans is a consistently grating, demeaning, terrible waste of my time."

“And spirits are known for being courteous conversation partners?" the nun replied.

"Excuse you," Sonneillon said, sneering. "Margaret, since when do nuns come with 
spines? It'd be an improvement if they still remembered manners."

Sonneillon had more prepared, but she saw how white Mother Margaret had gone. Her gaze kept flickering around the room.

"Sonneillon," she said, "Are you speaking to a nun, forty-ish, with dark, freckled skin?"

"I-" Sonneillon said. She looked at the nun, whose eyes were wide but her jaw set.

"Yes? What is this about? Has your prescription gone bad?"

Margaret clasped her hands in front of her chest. "So it's true. Lord, give me strength."

"What is going on?" Sonneillon insisted.

"Three weeks ago," Margaret said, "A nun here died. She was a dear friend; she spent years as my therapist, then gave everything up to join the convent. And now-"

Sonneillon caught on, and she felt a new sense of dread. "Oh no, Margaret, don't do this to me. I do not want to hear this.”

"You're hearing it," the Filipina woman said, and she rose from her chair, literally rose until she was floating four feet in the air above it. "And we have waited three weeks to tell this to you, so I'd appreciate it if you sat and listened."

Sonneillon had a retort half-formed when her voice caught in her throat. The nun was a ghost. Damnation, she hated ghosts. Ghosts and demons rarely got along, primarily because ghosts never knew their place. They were uppity little creatures, fresh from the offense of death, but Sonneillon had a stronger aversion towards them than most demons. Ghosts were unpredictable, frequently unstable, and prone to obsession; Sonneillon had been the subject of such an obsession, and now she shook to even share a room with a ghost.

"Margaret, I must be going," she said.

“No, Sonneillon, wait!” the Mother Superior said. “I can’t see Imelda, can’t hear her. She 
can move objects, but I can't help her move on. I need your help."

How was Margaret asking this? Why was she so cavalier? She didn't know, didn't understand. Sonneillon felt her anxiety rising. "I cannot, Margaret, I am sorry."

The ghost moved in front of Sonneillon, making her jump. "Please, Sonneillon," she said, pleading now. "I'm desperate. You must help me."

Sonneillon hurried to the door. "I really must be going," she called, voice shaking, and she wrenched the door open. The hinges clung to the frame even as the flimsy door tore away, its top corner and middle ripping apart like it was wet cardboard in her hands. Damn it, Sonneillon thought, she was losing control. The nun shrieked and backed into the corner, but Margaret stayed calm.

"Sonneillon," she said, "I need to speak with her. Only you can hear her. Please."

Sonneillon looked at the door, then at her only remaining friend. She had never told Margaret about these fears; it was too much to explain. "Margaret," Sonneillon said at last, "I am not a demon who helps people.” In fact she was selfish, had been perfectly selfish in every interaction with Margaret. She had no business expecting anything else.

Margaret crossed the room and stopped by the door. She looked as if she wanted to reach out for the invisible being in front of her, as if to rest a hand on her. She would have felt nothing if she had tried.

"I am not asking you to help," Margaret said. "But maybe you could be an intermediary so I can?"

After some coaxing and cajoling, Sonneillon managed to lure the ghost, Imelda, through the convent halls and into a small bedroom. She kept snapping at the ghost, telling her to hurry 
along, and then the ghost would fume and snap back. It was not very productive. Sonneillon was capable of greater patience, but frankly she wanted Margaret to get a sense of how fruitless her involvement would be.

Finally they got to the room, where Margaret was waiting for them there, sitting in the solitary chair facing the bed. Margaret's CD player was on the nightstand, the 'Anciients' album with its goat head and skeleton art placed neatly at the side while Christian soft rock played.

“Imelda's favorite," Margaret explained. She tapped the album. "We'll finish next time."

"Fine, I suppose. We are at the door right now, Margaret. Now I have passed through the doorway. Now the ghost has also passed through the door. What a good little ghost. So proud."

"My name is Imelda," the ghost-nun repeated.

"Yes, well, if you name something you'll want to keep it."

"Sonneillon," Margaret said, "Imelda was a dear friend to me. Please be civil."

Sonneillon did not want to be civil. She had already maxed out her quota on conversation for the day, the week, preferably the whole year, and now a Mother Superior — her friend — was ordering her to be polite? And she was obeying? She felt twitchy with frustration, and her urge to organize the room grew when she saw the little piles of books and CD cases at the window, the crooked sheets on the bed.

But. Ghosts had to be dealt with. They were pesky and needy and they frequently demanded help contacting loved ones, or carrying out revenge, or somesuch nonsense. There had been a time once, just shy of four hundred years ago, when Sonneillon had come across a whole village's worth of ghosts, Pequot women and children, who had been slaughtered by Europeans. Sonneillon and Berith, who was still with her, did their best to help. "Why are we dead?" or “Can anything be done?" she was asked, hundreds of times a day. "No," Sonneillon had said, 
awkward in their language, "You are dead. You only leave if you make peace. Try and make peace." Over the course of weeks, some got it; they'd get quiet, or smile and wish their loved ones well, and simply disappear. Others didn't; the tracker, a blunt-nosed woman, came to the demons day after day, insisting they find and kill the Europeans. Sonneillon grew to fear this woman's mad determination; she and Berith decided to remain invisible more often than not.

But, that was not the case here. Sonneillon looked at the ghost— a nun, of all things. Peaceful, complacent, faithful. Whatever she wanted, it would be probably be pious and selfrighteous. Sonneillon would feel safe once the ghost passed on, or, if that wasn't possible, the ghost could be convinced to stay put. That was the safest thing to do.

"Imelda," Margaret said, and she spoke as if it were all normal, as if two out of the three individuals in the room weren't incorporeal, "I have asked you to come here, to your old room, to discuss what comes next. Sonneillon will be our intermediary since I cannot hear you. With some patience, I am sure we can all work through this."

Imelda nodded. "How did I die?"

"The ghost wants to know," Sonneillon said, "Why she is dead?"

Margaret nodded. 'It seems to have been an overdose. Valium, though I don't know where you got that from. We haven't assumed anything," she hastened to add, but despite her diplomacy Sonneillon knew what that meant, "and the sisters are all grieving."

“Oh,” Imelda said. She looked at her hands. "Hm. Is there any way I could resume my work at the convent? I could pray, attend services?”

Sonneillon repeated her questions. Margaret shook her head.

"Doing the same things won't help you heal. Something must change."

Sonneillon cut in. "Come now, you don't know that," she said. 
"Margaret, you can't simply kick me out" the ghost said. "This is my home."

"She loves the convent!" Sonneillon repeated. "I think her staying right here sounds like a perfect plan."

"And I think she needs to get out," Margaret said. "She hasn't seen her parents in years, and they were heartbroken. Imelda should travel, and if you could escort her-,"

Sonneillon pushed the 'Stop' button on the CD player. "Margaret, no. That is not a viable plan. Your knowledge is centuries short of my experience. I value your input, but I need to take the lead. Ghost, I am the only being you know who can perceive you and will not harm you. Most demons refuse to tolerate ghosts, so count your blessings, as they are."

The two women looked exasperated at the outburst, but they kept quiet.

"Simple facts," Sonneillon said. "You are a ghost, which only comes from humans. Not all humans become ghosts, that's usually a thing for extremely dissatisfied folks. Ghosts mostly just float around until they get over their emotional problems then go away to whatever's next. I don't know what that is, by the way, though I know you nuns have theories." Sonneillon almost smiled to herself. She was summarizing a speech from Berith long ago, though probably with much less patience and sympathy. It was a shame she was gone; she would be so much better.

“So that's it?” Imelda said. "I'm here until I address my unresolved issues?"

"Yes, that's exactly it. Some alone time, some cathartic tears, and you'll be off. Isn't that right, Mother Superior?"

Margaret frowned. “That's a fair summary. Imelda, I want you to know we've followed the instructions left in your will. We sent word and money to your family, and the college as well. The sisters will take whatever personal items they wish, then the rest will go to charity. Is there anything else you feel we can do?" 
“My will. Dear God, I'm dead and they used my will," Imelda said. “And you won't even let me stay here, my oldest friend? Margaret, you're kicking me to the curb."

"She says you're kicking her out."

"I am not," Margaret protested. "I am acting on your advice, Sonneillon, so help me convince her."

“Oh of course, Mother Superior! Thy Will be done," Sonneillon said.

“Tell me this, Sonneillon," Imelda said, and Sonneillon bristled at the tone, even if they were ostensibly on the same side at the moment, "Is it possible I am a ghost because I have unfinished work?"

“That's a bit cliche,” Sonneillon said, "But maybe. In my experience ghosts happen when there is some trauma. Maybe something with one of your sisters at the convent? You could stick around and figure it out."

“Ask the Mother about my special project," Imelda said. She did.

Margaret looked surprised. "Imelda, you are acting in haste. Let's talk."

"One of your primary concerns was the risk to my well-being. That is no longer a concern, right? I am a literal ghost.”

"She says she can't die. What is this about?" Sonneillon demanded.

"You know my misgivings," Margaret said, directed toward Imelda. "But I shared them many times with you. You want to try? Ask her yourself."

Imelda nodded and stood. She removed her habit, uncovering a dark head of short, curly hair that had surprising streaks of grey. She looked at a spot very near Sonneillon's head, unnervingly so. "Spirit Sonneillon," she said, "As a nun of the Catholic Church and the recipient of a Doctorate in Psychology from UCLA, I would like to formally offer my services as a 
clinical therapist to you."

Sonneillon blinked. "Oh hell no," she said, and she fled the room.

Almost two weeks later Sonneillon decided to give up and return to Tennessee. She had made it as far as the mountains in southern New York, almost to this lovely town called Warwick, all the while traveling by night and hiding in tree branches. These were ridiculous precautions considering she was still invisible, but she couldn't convince herself she was safe otherwise. It was so frustrating, not just because she was missing some of her favorite overlooks but because she was always checking over her shoulder, always starting when she heard voices or when a bird took flight. She was imagining ghosts on her trail, the ghost-nun rambling about psychology and the Pequot tracker-ghost ranting about revenge. It was her "anxiety" acting up, she told herself. That's all. Just her anxious, panicky, prone-to-night-terrors-and-violentoutbursts quirk. She could cope with that.

But what she couldn't cope with were the Ouija migraines. She'd told Margaret a bit about them before: low buzzes in your head that grow louder and set your mind burning. Any demon within a few miles of an Ouija Board would feel it in use, which was a big part of how they attracted demonic attention in the first place. Usually unhappy attention, and Sonneillon was very unhappy now. She had been getting the buzzing every night since she left Tennessee, which was not only painfully maddening but defied what she knew of Ouija Boards. She was hundreds of miles away; was she being followed? Was some hiker carrying an Ouija as they traveled the Appalachian Trail? But she was doing twenty-plus miles a day, faster than any hiker. So she turned back, not because she knew how to solve the problem but because she knew running had done her no good. 
Two weeks after that, Sonneillon finally found the source of her suffering. She was back "home," as it were, in the Tennessee town with Margaret and the convent and all the little burrows Sonneillon liked to stay in. That was when she felt the Ouija throb in her head, except much stronger than before. It made her gasp when it hit her, like getting a migraine at a metal concert in the space of a second. And now she could feel something else, something she had never experienced before: she could tell what was being spelled, over and over again, into the Ouija. S-O-N-N-E-I-L-L-O-N.

She traced the pain to a house she had visited before, the house of the high school girls that had been bothering her weeks prior. Idiot teenagers, would-be witches; she would fry their iPhones and tear their Hasbro brand board game to shreds. Sonneillon gritted her teeth through the pain and entered the house through the chimney. She made her way quickly through the living room, scratching furniture and toppling family photos without looking at them, then coming to Sara's bedroom door and slipping in beneath the crack. The girls were there of course, hunched over a makeshift Ouija board drawn on copy paper with blue pen. And hovering over them was the ghost, still in her black tunic, her headgear missing and her dark hair frazzled.

"What in the ever-loving hell is this?" Sonneillon demanded. She used her powers to speak in a way that only the ghost would hear, but she was practically shouting.

The ghost turned to her with a look of surprise and joy. "It worked, it worked!" Imelda cried. "Oh Lord, thank you, finally!"

"What is the meaning of this?" Sonneillon blustered. This is absurd, she thought, stupidly improbable.

Imelda grinned. "I needed to find you but I had no idea how, and I thought, Imelda, what do you even know about spirits?" The ghost landed and paced the room excitedly, talking with 
her hands. "I mean I had asked Mother Margaret about you many times, but most of what she said was about how hard you were to find. 'I never contact her, she contacts me.' All I had was meta-data, not even details, and Mother sure isn't sharing any more, especially since she never knows when I'm around!"

"How did you find me?" Sonneillon demanded, but she was extremely distracted; the throbbing was still going strong.

"I read the literature," Imelda said. "Fathers Reitman and Feig detailed the attributes and inner workings of Ouija Boards as they pertain to spirits in 1984. If you spell a spirit's name, they will feel it no matter the distance. Mother Margaret gave me access to those files."

“The Mother Superior helped you summon a demon with a Ouija Board?”

"No," Imelda said. "She gave me access to the Church's files on ghosts years ago, when I was still just a therapist. And your history with Mother Margaret, including your most recent visit, confirmed that you would take proactive steps to halt any Ouija activity. This was the quickest and most reliable way to contact you."

Sonneillon wondered if the Church's documents mentioned the terrible pain Ouija boards could cause her. From the appraising look the ghost had, Sonneillon suspected they did.

The ghost's posture shifted. "Sonneillon, in the short time I have known you I have witnessed aggressive and antisocial behavior. It is my belief that you could be a happier spirit if you addressed some of the issues in your life, and as a former therapist I know a number of ways to help with that. If you will let me, I would like to see what methods fit in with your lifestyle and develop better means of coping."

"You think I am crazy?" Sonneillon said. "I told you you have your own problems, and your solution was to stalk teenage girls!" 
“Stalk?” Imelda said. “Oh no, no, I haven’t stalked them. I just drop by in the evenings and encourage them to play with the Ouija."

Again, Sonneillon was cut short. What kind of nun was this? "You what?"

"I encouraged them," Imelda repeated. "Sara's mother threw out their first board, but then they made this one. For three nights I spelled your name, and now they do it on their own, hoping it will summon the demon back. Which I suppose in a way it has. But don't worry, I've put it to good use."

She turned to the girls, who had their chins on the desk, clearly disappointed in the paper football-planchette's lack of movement. Imelda got an intense look of focus, then placed her hand on the football and slowly, methodically, dragged it across the page. The girls gasped, then grabbed their notebooks and copied every letter.

“E-I-G, wait, was that an H or another I?" Bethany said.

“Oh my God, Bethany, shut up,” Sara snapped.

The throbbing in Sonneillon's head redoubled. "Stop it, ghost, stop this right now."

"Almost done." The football darted all over the page, then finally came to a rest.

"YOUNG WOMEN NEED EIGHT HOURS OF SLEEP," Sara read aloud. The two girls waited, then looked at one another.

"I'm going home now," Bethany whispered. "To rest." Sara nodded, and Bethany hurried to pack her bag.

“See?" Imelda said, turning back to Sonneillon. "Nothing but health tips, physical and mental. They're both flossing every day and journaling, thanks to me."

"Well, God sure does provide a way, doesn't He?" Sonneillon said. "Or if not, then you can always manipulate children to get what you want." 
This was all very bad. It turned out that Sonneillon had a well-informed, highlydetermined stalker who believed she was on a holy crusade to cure her. Her anxiety kicked into high gear, but she fought back the fear and tried to talk her way through this.

“Listen_ 'Imelda,' was it?__" Sonneillon said, "You've spent too much time as a ghost. I've seen this before; it's not healthy. You'll get obsessive, then aggressive. You'll never leave."

"Is that why I can see you?"

Sonneillon recoiled, pressed her back to the wall. "No you cannot!"

"Not fully, no. But I see a hazy outline. You look about my size."

"Then that is proof!" Sonneillon said. She spoke with her firmest, most authoritative voice. "Ghost, let me be clear: you need to give up on fixing me and just fix yourself."

Imelda was deep in thought. "I did not know all that," she said, then looked, unnervingly, directly at Sonneillon. "Perhaps I could direct you to another therapist? I have a friend practicing in Charleston, she wouldn't even have to know_-"

“Oh my God!” Bethany cried from the living room. Sara ran from her chair to the door, then clasped her hand to her mouth. Imelda's eyes went wide and she followed Sara.

“No, ghost, wait!" Sonneillon said, but she narrowly missed grabbing her.

"What did you do?" Sara cried, but it was clear Bethany had not done any of the horrific damage to the room and furniture there. The sofa cushions were torn open from end to end, the white guts spilling out where Sonneillon had split them, and the walls and carpet bore some of the same long scars. Just outside the bedroom, picture frames lay shattered on the ground. Broken glass stuck up out of the carpet, and Bethany leaned against the wall, clutching her foot as blood seeped out of a gash and soaked her leather sandals.

Sara grabbed Bethany by the arm and practically dragged her back into the bedroom. She 
slammed the door closed and locked it behind them.

"I'm calling 911," Sara said. She tried to dab at Bethany's blood with the sleeve of her sweater, but Bethany turned away and cradled her foot, still sobbing.

"It was the Ouija, the ghost!" Bethany cried. "What did we do, oh my God, what did we do?"

Sonneillon tried to leave, tried to slip out under the door. Imelda grabbed her arm. The ghost's grip was firm, and it sent terrible shivers through Sonneillon. "Stay," was all Imelda said. She did.

Bethany went to the emergency room in an ambulance. Not because she needed all of the attention, Sonneillon was certain. The medics and cops had practically forced Bethany and Sara out of the room, and only once they promised to stay with the girls; Sara's parents were nowhere to be seen, somewhere out-of-state, it seemed. Bethany was in hysterics the entire time, but Sara helped calm her down. "It was probably just a robber, ok?" she said, which helped Bethany calm down. Sonneillon thought the looks of confusion from the medics were entertaining.

Imelda was not amused. She waited in that room until everyone was gone, hours later, after every last medic and police officer had taken their leave. Then she let go, finally, at last, thank God, let go of Sonneillon, and she could move freely again.

The first thing she did was place her back to the wall. Imelda had been relentless. She dragged them around the room, getting a better angle on Bethany's tear-streak faced or the police arguing in the corner. She seemed to regard the experience as punitive, and the nun had kept glaring at Sonneillon. Look what you've done, she seemed to be saying. How could you?

"What do you have to say for yourself?" Imelda said. To her ears it probably sounded 
reasonable, measured; to Sonneillon it sounded puerile.

Sonneillon breathed deeply, took a moment to enjoy the silence. "You would call this 'Post-Traumatic Stress Disorder,"” she said, “Though I have had it longer than humans have had a name for it. My symptoms include anxiety, obsession, aggression, and, I don't know, poor social skills, perhaps.”

Imelda looked surprised. "You don’t know?” she said.

"I was never especially social," Sonneillon said. "It's hard to distinguish symptoms from personality when you are so used to being yourself."

"This is . . surprising insight," Imelda said. "I was not aware you are a student of psychology."

Sonneillon actually smiled at the ghost's attempt at a joke. "I knew about psychology before it had a name, too. And I appreciate all its titles and descriptions, I do, but it's still afterthe-fact, a bunch of invented words. I suppose they're helpful." In truth she wanted to avoid the subject, as she had done for the three hundreds years she'd endured PTSD.

Sonneillon had watched the Pequot tracker-ghost kill a demon. The ghost had gotten ahead of them somehow, had hidden within a lake and waited for them to pass. Sweet Berith, who stopped and sighed at every pond, now dragged into the water screaming. Sonneillon turned and saw the attack, saw the tracker with her mad eyes and her strong arms around Berith's neck. She's a demon, Sonneillon thought then, and remembered that the title was not an honorific, as Berith had always claimed, but a curse, the fate of ghosts who could not find peace. The water did not move when the tracker and Berith slipped in, nor when Sonneillon dove after them.

Sonneillon was giving Imelda — the ghost— exactly what she wanted. She knew that. But she genuinely felt for the ghost, regretted that the woman would be reduced to this state. 
Whatever was keeping her around, whether it was her obsession, her suicide, or regular old Catholic guilt, she didn't deserve to wander all over the earth forever. God, who did?

Imelda looked up at Sonneillon again, frustration showing on her face. "You are doubly responsible for your violence, then."

“Excuse me?” Sonneillon said.

Imelda nodded. "You knew, have known, that you suffer from PTSD, and besides that have a tendency towards violence, and yet you have done nothing to confront this fact. Do you feel no responsibility? Did you think it would treat itself?"

"There were extenuating circumstances," Sonneillon said. She was surprised at being addressed so rudely. "What kind of therapy are you offering anyways, the 'Shout-at-You-UntilYou-Get-Healthy' method?"

Imelda stood up. "Come on," she said, "We're going to clean up your mess."

Sonneillon followed the petulant brat out the door and into the living room, where the police had already done the bare minimum of cleaning up. Imelda crouched low, straining to pick up individual shards of glass. She was, of course, only barely able to interact with the physical world. Sonneillon sat on the back of the ruined sofa.

"You know, you are so right. I clearly need help, Imelda, though it pains me to admit that. It's just so hard opening up to someone I know so little about. Could we change that, do you think? What can you tell me about yourself?" Sonneillon said. The ghost ignored her. "No? Shall I use my demonic powers to read your mind instead?"

"You have no such powers."

“True," Sonneillon admitted, smiling to herself, "But I do a good job at guessing. Let's see, you said UCLA, right? I am sure you were the pride and joy of your family, especially your 
first-generation Filipino parents. 'Imelda' isn't that common a name in the states, is it? They worked long hours, bland jobs, but it paid off to see their daughter get that doctorate. Of course you threw all that away when you became a nun, so.”

"What you are doing is called 'deflection,' Sonneillon."

“Oh no, I respect that choice, I really do," Sonneillon went on. "Because really, the cushy therapist life was sort of disrespectful to your hard-working parents. Don't you think? Vows of poverty are great penance for years of sucking them dry.”

"You are trying to hurt me because you do not know how to help yourself," Imelda said.

“But even that wasn't flagellation enough, was it? Not enough pain. You had to swallow a bottle of pills for dinner, because all your cousins are maids or worse in the slums of the world."

Imelda bolted upright. "What could you possibly know_-" she demanded, then stopped herself. She was clutching the glass so tight her palms were bleeding. Imelda probably hadn't known it was possible for her to bleed, but it happened because she wanted it to happen. Sonneillon had figured the ghost out; she wanted to bleed.

"Oh, perfect," Imelda said, and just then there were lights in the driveway. Imelda hurried to the kitchen, dropped the glass into the wastebasket. She bunched her hands up in her tunic. "We need to get out of here."

Sonneillon did not move. The front door opened, and in came a couple in their forties or early fifties. They were clearly Sara's parents, especially the father, who had the same widow's peak. The mother, a surprisingly tall woman, went immediately to a hall closet.

"I've got the duffel. You'll get the bathroom stuff?"

"Right, right. Toothbrush, toothpaste, shampoo?" 
"There'll be shampoo at the hotel."

The couple scrabbled Sara's belongings together. They both smelled like cheap coffee, and Sonneillon could see deep bags under the father's eyes. They had clearly been driving for hours. The whole time Imelda cowered in the kitchen doorway, like she expected to be caught.

The duffel stayed in the living room as they filled it with Sara's stuff. When the wife finally found Sara's back-up tennis shoes, she returned to find her husband staring at the shredded sofa.

"I should buy a gun," he said, and Sonneillon felt pity and scorn for this helpless man.

"Todd, come on," his wife said. She stuffed the shoes into the bag and zipped it up.

“This neighborhood isn't what it used to be. I should have a gun. I can't take any more business trips." He was choked up, his shoulders clenched. The woman avoided looking at him, just hoisted the duffel onto her shoulder.

The two of them left. They hadn't even turned the car off; they left it running in the driveway and the headlights shining through the front window. Why hadn't they turned on the living room lights? Sonneillon thought. It's their home.

The house returned to silence and darkness, and Sonneillon let a few minutes pass thinking about Sara's pitiful parents. They had seen their home destroyed, their daughter's life endangered, not to mention Bethany's. It was terrifying, certainly, but what could they do? Collect insurance, change houses, hope demons stayed away. They so desperately wanted to feel in control; Sonneillon could respect that.

"Have you heard of 'Unconditional Positive Regard?"” Imelda said, so suddenly Sonneillon jumped a little.

"No, can’t say I have." 
"It's important in therapy," Imelda said. "It's the idea that no matter what the patient says, no matter what they tell us, we will accept that person and trust that they can change. No exceptions."

"Sounds hard."

"Mhm."

"Sounds like you'd have to fake it sometimes."

Imelda smiled a little. "Sometimes. But it's necessary. It's sort of modeling selfforgiveness for the patient — we can recover from almost anything, but people cling so hard to their mistakes, their old ways."

Sonneillon came down from the couch. "You think Sara and her parents will forget all this, move on?"

"Perhaps," Imelda said. "With time."

“I don't think so," she said. "Trauma is something you live with. You only add it to your life experiences, never heal and subtract. You see what I'm saying? It adds up."

"I'm not sure I follow," Imelda said. "Are you saying people don't change?"

"No," Sonneillon said, "I'm saying they are forever changed. Your positive regard doesn't fix that. At best it staves off the fears just long enough."

"Long enough for what?"

“Long enough to die,” Sonneillon said, “and forget. That's why I can’t do therapy, Imelda: I can't die. Maybe I'll behave for the next five, ten years. But do you think, in terms of simple probability, that I will never have another fit, or another outburst, ever again? In the centuries and millennia to come? Ten years would be a miracle. Do you think I can possibly preserve my sanity that long, that I won't eventually become a raving mad demon preying on 
innocent families? Your 'Unconditional Positive Regard' is conveniently short-lived for people like me."

"Mine isn't," Imelda said. She held up her hands; the blood and the cuts were gone, completely erased. She had refocused on Sonneillon rather than herself. "Not anymore."

Sonneillon backed away, tentatively stepped into the air. "What are you saying? You'll follow me forever?"

“No. I know I can’t force you into anything. I don't want to. But, if you want, and if you let me, I will listen to you, and I will try to help you."

"It is pointless," Sonneillon said. "A band-aid, nothing more."

“I don't think so," Imelda said. "I think, given enough time and work, you will heal. Who knows, you may even outgrow your sins."

Sonneillon backed further away. "'Outgrow'? That doesn't sound very Christian of you." Imelda took another step. "I don’t think there's a hope more Christian."

That was that; there was no deterring the ghost. Sonneillon turned, dipped low to the ground, and flew up the chimney, rushing to meet outside air. Distance was what she needed, and she'd persevere through the Ouija migraines until Imelda gave up. Of course Imelda would give up, she didn't have the determination of that Pequot tracker, the damned obsession. She'd leave Sara behind, Margaret behind, the therapist ghost all left far behind, and not a single one of them would ever catch her or lay a hand on her, not now, not ever.

A hand grabbed Sonneillon's leg just as she rushed out of the chimney top. It was the therapist, literally on her heels, gripping Sonneillon and flying to keep up.

"Sonneillon, wait!" the ghost said.

"I told you not to chase me!" Sonneillon said, scrambling above the rooftop. It was the 
old fear, the panic that made everything a threat. Good God, she could not live like this.

"I killed myself so I could help you!"

Sonneillon twisted hard, breaking free of the ghost's grasp. She kicked again at Imelda's head, but again the ghost snatched her leg and yanked her in. She felt like her movements were slowed, like she was underwater. Imelda was lying, she had to be. Sonneillon felt her fear mix with rage, and she spun and slammed her arms into Imelda's chest, driving her into the slate roof and pinning her there. The ghost cried out, but she was cut short when Sonneillon jammed her elbow into Imelda's throat.

"You know what?" Sonneillon said, seething, "You were wrong to think you are safe from me. I am the only thing that can properly destroy you, that can crush your throat until the stubborn part of your soul lets go. I tried to tell you how to go the nice way, I told you what lines not to cross, and still you ignored me?"

"I- I don't believe you—" Imelda croaked.

"You don't believe me? I have done it before! This goddamn obsessive Pequot bastard, she wouldn't let me go, hunted me and threatened me after all others had given up. She killed Berith, would have killed me! I caught her and crushed her throat in the lake, and I will do the same to you, do you understand? I will not let you do that to me!"

“Then stop me," Imelda said, her eyes wild. Sonneillon wanted to, badly.

Sonneillon threw Imelda, threw her bodily into a nearby oak whose branches snapped and crashed beneath her. Then Sonneillon turned and rushed down the rain gutter, then flew out in the shade of the house, then into a storm drain and through the sewers. She kept on moving, kept on twisting and crying and hiding well into the night, before she finally slipped out a manhole and into the cemetery. She picked a headstone, pressed her back to it, and waited, waited and 
prayed that she would finally move on, finally be taken like all the other ghosts and be blinked out of existence.

Once again her prayers went unanswered.

Two days later Sonneillon got up. It was a good day to move about, she thought: the sky was clear, the sun was warm, and the earliest signs of fall peeked through the otherwise green trees. It was also a good day to move because two college students were fondling each other in Sonneillon's line of sight, rolling in the grass as if no one could ever pass through. Dumb teens, she thought with a smile. So Sonneillon decided she needed a change of location. She wasn't aggravated, she noticed with some mild surprise: the boy was very polite, he asked permission anytime he went to kiss somewhere new, and the girl clearly enjoyed giving her consent. She would have tuned them out or scared them off, but it was fine, really. They would make better use of the spot than she had. She touched the tombstone as a farewell. "II hope you died quick and I hope you died clean," she said, quoting one of Margaret's songs, and she was off.

Sonneillon lazed over the small town, looking over its grocery stores and high schools and at the fields beyond. It made her anxious to be so exposed, even knowing she was invisible. She stayed put. She thought of Berith. Of the demons Sonneillon had met, Berith was the only one she had thought might actually pass on. She was not right in the head, of course; no demon was. But Berith was chatty, always willing to talk about her tribe, her pregnancy, her death. Wasn't talking supposed to help? She used to wonder aloud what happened to her kid. It was like a game of let's-pretend, where Berith and Sonneillon spun stories about the son who became a prince or the daughter who studied astronomy. There was a constellation that only Berith and Sonneillon knew about, which they named Aset after the imagined daughter; you could see it from Berith's resting place if you sat on the shore in the winter. 
Sonneillon spent another few hours wandering back and forth over the town before she went to see Margaret. Both the Mother Superior and Imelda were there. The tape player was on Margaret's desk, and it played some of the Christian music as last time. Margaret's whiteboard said, "Five PM: Steven Curtis Chapman, Music of Christmas. Six PM: Anciients, Voice of the Void." Margaret looked like she had cried recently, and Imelda sat hunched in a chair.

“Ah, hello," Sonneillon said, making both women jump. “Am I interrupting?" "Sonneillon!" Margaret said. "Is that you?"

"Yes," she said, "Though Imelda is here as well. Did you know?"

Margaret's face broke into a wan smile. "No, I did not," she said, "But I had hoped so. I've scheduled times where she can hear her favorite music. I missed listening with her. Can you ask her how she is doing?"

Sonneillon used the voice that only Imelda would hear. "She likes Christian rock?" Imelda nodded. "We used to listen for hours. She said it reminded her of her childhood." She had a strange look on her face, like she was afraid to say much more.

Sonneillon spoke audibly for Margaret. "Is 'Anciients' supposed to be for her, too?"

"That was in case you wanted to drop by, Sonneillon."

"You really are all things to all people, aren't you?" Sonneillon said warmly. She pulled an empty chair away from Margaret's desk and placed its back against the wall. She sat down.

"Imelda is not very well, Margaret," she said. "She committed suicide just about a month ago, which was understandably distressing. These sorts of things are best dealt with sooner rather than later. As her mentor and religious leader, I think you should be meeting with her regularly."

Margaret was a master of carefully-controlled faces: the one she showed now spoke of interest but also caution, as if to say, How interesting, Does anyone else have any thoughts on 
this? "Have you discussed this with Imelda?" Margaret asked.

Imelda's eyes were icy, her lips pinched. "I wasn't being honest when I said I died for you. That was - I was desperate. I'm sorry. But I did stay for you," she said to Sonneillon. "I am a ghost because I know you need help, and I will help you."

"No," Sonneillon said to Margaret, "This is the first she's heard about it. But these problems get worse with time; if she is supposed to find any peace, she needs to act."

Imelda clutched the edge of her seat. "You are a violent misanthrope with poor impulse control, and the fact that you think I need help shows how little self-awareness you have. Now please," she said, "Let me help you."

"And you realize," Margaret said, and this time her face spoke of concern, apprehension, and some small degree of hopefulness, "That I cannot help Imelda unless you attend therapy and speak for her?"

Imelda blinked, then sucked in breath. Sonneillon nodded. "I do."

The three women sat in silence for a little bit. Margaret's hands were folded over one another, while Imelda drummed her fingers nervously on her knee. She looked frightened but thrilled, and she seemed entirely unable to tear her eyes away from Sonneillon. Sonneillon felt just as frightened; she had not forgotten Imelda's obsession, her own capacity for violence.

"Well," Margaret said. "We could start now. Would either of you like to start with any background information, to help us get started? I do have the next couple hours blocked off." Sonneillon did not actually know what to do next. She'd come on an impulse, but now she was imagining escape routes. Invisibility was her safety net, plus speed. She kept eyeing the door, the windows, Imelda. How could she come here? What possessed Sonneillon to do this?

"I just_-" she said, then stopped. "Margaret, please tell me I'm allowed to move around 
rather than sit in your rickety Goodwill chair?"

Margaret smiled. "You may."

Sonneillon lifted into the air, then immediately darted underneath Margaret's desk. Drat it, the Mother had knocked over her dust bunny piles and paper clip stacks. She set about arranging them at once. "Well, I imagine there will be some hiccups at first, of course. I am not a patient woman, you both know that, ha, and the whole business of translating for Imelda? That will be trying. But aside from that there are cultural problems, namely that of the extreme distance between when I was alive and when either of you were alive.” The clips and bunnies were tidy; Sonneillon went to the wastebasket, hardly listening to herself talk. "That was practically prehistoric, and most of what I remember isn't helpful, I couldn't point it out on a map, but that's a nomad for you. We actually left navigation up to an old friend of mine, Berith. In life she had hunted, and she knew the stars. And our informal leader, Jar, chose our destinations. He was quite a kind and gentle man for many years, and nowadays he'd be called a 'cultural tourist.' He liked local customs, the feasts and marriages that brought all of the people out, and on occasion we would mingle with the humans. You'd be surprised how welcoming they were then, whether we presented as strangers or spirits; for them we were part of the fun. And once I was declared the Festival Priest! I won a contest of poetry and insults, trading jabs with a delightful fat farmer, and Jar placed the golden mitre on my head and everyone cheered and we were laughing for days." Sonneillon paused and looked over her handiwork. Wastebasket sorted, plugs plugged, blinds straightened, dust dusted, even some cobwebs in the corner swept away and spooled up on a bookshelf. Very good, Sonneillon thought to herself.

“Were you invisible the entire time?" Imelda asked.

“Hm?" Sonneillon said, coming out of her reverie. Reality came rushing back, and 
Sonneillon remembered that therapy would not cure her. That was immutable, as far as she was concerned; what could ever undo centuries of fear, paranoia, of friends losing their minds and watching yourself do the same? Jar had turned violent in France, Berith was manic and prone to the same rages as Sonneillon. And just days ago Sonneillon had almost killed again. What would Berith say if she saw what her friend had become?

Well, Berith would tell her to get help. "You deserve the best," she had always said. Sonneillon wanted to do what would make her happy.

"Hm?” Sonneillon repeated. “Oh, was I invisible at the festivals? No, not at all. I looked like this."

Sonneillon let herself take a visible form, an old one she sometimes slipped into for comfort. Her skin was dark and deeply lined with age, though only her face and hands were uncovered. Her tunic was heavy and plain, a simple brown material that hung onto her thin shoulders. But she wasn't frail, didn't appear as a bent old woman; her arms moved steadily, smoothly, and her long, square face looked as if it had withstood years of desert sun.

Margaret couldn't help but look surprised to see this stranger appear in her office, especially to see her floating near the ceiling and dusting an air vent. "Sonneillon, is this your original form?" she asked.

"Something close to it," Sonneillon said. She still felt frightened; she wanted to leave. But she felt bold, like each snippet and story were victories of their own. She gritted her teeth into a smile. "I kept the mitre for years, though I don't think I was supposed to. I don't remember what came of it. I might have left it with Jar in France, not long after we started calling ourselves 'demons."”

"But Sonneillon, why call yourself such a thing?" Margaret asked. "Why such an ugly 
name?"

"It is something of an insult," Sonneillon agreed, "But it's also an identifier, something our kind can hold onto. There's nothing like meeting someone who understands what you've been through."

Sonneillon felt tired all of a sudden, and she let the air vent be. It was clean enough. She drifted down to her chair, still against the wall, and sat down, holding her arms across her chest. "That's all for me today, I think. Sorry if it was a tad dull."

"Not at all," Margaret said. She gave her friend a gentle smile. "Thank you."

"I remember how I died," Imelda said. Sonneillon looked at her with surprise. Imelda held her stomach, her neck was bent, and her lips were set as if staying upright required an act of will. “It was pills, you were right. I felt like I wasn't doing anything with my life, like I was a waste. Tell Margaret I am sorry. The self-harm came back; I should have told her.”

"It's okay,” Sonneillon said. “"To err is human,' right? Or so I've heard." Imelda wiped her eyes. "I was a therapist, Sonneillon. I should have known better." Sonneillon thought how silly that logic sounded; people are always doing what they ought know better than. But who was she to talk? She took Imelda's hand in hers and gave it a squeeze.

"All of this will get easier. In spite of myself, I do believe you can do it." And Sonneillon repeated Imelda's message, word for word, so Margaret could listen and tell her the same. 


\section{COMMUNITY FAIR}

The Ragland Community Center's long hallway was filled with festival items organized by club and by heft, the only bend nearly blocked with the tents too heavy for Craig to carry on his own. Two weeks before the community fair the clutter had still been light: the banners and signs stretched across the floor for painting and touch-ups, and he only had to sidestep a little here and there. But then it was the week of and every hour he had to snake around some new cotton candy machine; stacks of safety cones and reflective vests; the tacky cans of spray paint; the balloons, tanks, and string the clown needed; the slowly growing assortment of tables, glitter, glue, garbage bins, binders, bunting; the chairs, the coolers, the first aid kits, the defibrillators and the tarps, until it was one in the afternoon and three days before the festival and Ms. Charlotte stopped Craig to talk.

"Three days now!" she said. "Isn't that something?"

"Yes," Craig said.

"It seems to come up faster and faster each year!"

"Really," Craig said.

Ms. Charlotte put her hands on her hips. “And I've got so much to do! Isn't it wild how much there is to do and how very, very little time there is?"

Something had disrupted Craig's blessed invisibility and brought Ms. Charlotte's scrutiny to him, but he sure didn't know what. Craig decided to ride it out in silence.

Finally Ms. Charlotte shook her head. "Craig, I was wondering if you might help me out. Everyone's been signing up volunteers for months now but you've got no one."

"Oh." Craig looked around for something to carry away from there. 
"I got mothers from the daycare, Jackson got all his clubs, and a few people signed up on the bulletin board. That's almost enough."

“Good." He crammed Kool-Aid tubs into his arms.

Ms. Charlotte stopped him. "But it's not, Craig. Not enough. Have you asked any of your assigned clubs?"

"Not yet?"

“Not yet. You work at a Community Center. Didn't Americorps tell you this was a social job?"

Craig cringed; he didn't have a good answer. "I do work hard. I keep everything clean, I carry stuff for people. I do well at that."

"So let's improve," she said, taking him by the arm towards the building's foyer. There was a group of older folks chatting, all dressed in sweater vests and cardigans despite the May heat. "The Lion's Club loves volunteering! Go to their meeting. Goodness, go to all your meetings like we've been paying you to do. And get me some volunteers, or," and she paused, clearly uncomfortable with ultimatums, "Or we may have to discuss letting you go early."

There wasn't anything wrong with the Lion's Club as far as Craig knew, but every member had spent decades collecting Ragland's used glasses, not to mention decades more living there. The incredible weight of their comfort seemed to press Craig out, as if he could never have such security. He tried to slip into the back corner unnoticed.

“Craig!” It was Jackson, a part-time-turned-full-time worker. His permanent smile and perfectly tousled Latino hair made him look continuously at ease. "Here to watch the meeting?" Craig shook his head. "I'm supposed to be finding volunteers for the fair this weekend." Jackson beamed. "That's great! It's so, so important to give back to your community, 
don't you think?" When he didn't get a response, Jackson went on. "I already got some of them to sign up, but I'm sure we'll get a few more volunteers somewhere! Have you checked with their volunteer coordinator?"

Philip, the Vice President for Volunteer Coordination, was a squat man with wild white hair and an impatient glare. He cut Jackson off mid-introduction.

“Don't let me hear you call me 'Mister,'” Philip said, pressing a lighter to his cigarette. “My dad was 'Mister Philip.' You can call me 'Captain Philip.””

“Oh?” Jackson said. "I didn’t know you served, Philip!”

"I didn't. Flat feet." Philip puffed. "But if I had I would have made captain. What do you want?" The fierce old man turned his eyes on Craig, whose anxiety redoubled.

"We need volunteers. The Community Center needs volunteers for the fair. We need helpers anytime between seven and five," Craig said.

“So what?" Philip coughed, not even covering his mouth. Craig could feel spittle on his arms. "Listen, do you know where you are? This is the Lion's Club. It exists for lonely old geezers to feel needed." He gestured to the group. "Most of these dumb raisins would sit out in the sun till they got heatstroke. But that's not happening, bucko."

Jackson cut in. "Come on now, Philip, it's a good cause. Can't you help him out?" "No," Philip shook his head. "If it were you, Jackson, maybe. You know I like you, but this kid? Asking me to offer my people for free labor? I decide which projects are appropriate for our members, and I don't like this one.”

"You're being unfair," Craig said. He knew he'd be bad at recruiting, but he was not prepared to get shut down so cruelly.

“Shouldn't the members get some say in it, though?” Jackson said. 
“Ha!” Philip laughed. He picked up his old splintered cane and smacked it against a table. The room turned to look at Philip, and a tall, thin black woman spoke up.

"You have something to say, Captain?" The woman's gaze jumped right over Jackson and landed on Craig.

“Actually, Maggie, it's someone to introduce!" Philip said, giving a dramatic half-bow. “A kid who wants to explain to us why we should volunteer for him!” Philip waved to Craig, and all the eyes in the room, save for a few wandering ones, turned to him. Craig began to sweat.

"I need volunteers," he began.

"Please go to the front, young man," Miss Maggie said.

Craig shuffled to the front, stepping past walkers and oversized bags. He'd just speak quickly and end it soon. He turned to face the group.

"Hi, my name is Craig Marsden," he said. "I am 22 years old and I am here with AmeriCorps. I work at the community center Mondays through Fridays.” No signs of recognition. Craig rushed on. "This weekend is the big community fair and it's an annual celebration for everyone here plus some other towns nearby. There will be live bands and rides and prizes and stuff and we need people to volunteer to help clean things up, man some stations, pass out water, sit at the first aid station, I don't know, lots of stuff, and we'd really like help taking things down because we found out there's a softball game in the field that evening so it all has to be clean by four."

Maggie looked him over, then turned to Philip. "Captain?"

"Hell no."

Maggie shrugged. "Sorry Mr. Marsden. We must decline."

Seconds later Craig was out the door, head down as he scooted around the elderly folks in 
his way. He needed to be away from all these eyes; the attention made him feel sick. He found a half-second of peace in the hallway before Jackson caught up.

“Hey buddy, wait up!” Jackson’s smile fell when he saw Craig’s face. “Craig, are you alright?" he asked.

Craig shook his head. "Sorry. I got a little stressed. I'm sorry."

“A little stressed?" Jackson said. "You look more than a little stressed. Come on dude, let's take a break. I'll buy you a snack."

Jackson coaxed Craig into the break room and calmed him down with his chatter. Little by little he convinced Craig to tell him about Ms. Charlotte's ultimatum.

Jackson shook his head. "Wow man, for real? I didn't know any of that." Then he hesitated. "And you getting fired would be ... bad, right?"

Craig wasn't sure what he was asking. "Of course it is. Why wouldn't it be?"

Jackson looked embarrassed; Craig discovered he liked seeing him off-balance. "I mean I want you to stay. Of course I do! It's just I wasn't sure if you liked it here. You kind of keep to yourself. And besides," he said, "This is only a one-year position, right? So maybe you'd get reassigned; worst-case you go home and find a new job."

Craig suppressed a flinch. He was in Ragland precisely because his hometown was no longer an option for him. He'd grown up the weird kid there, the distracted, effeminate guy. His dad hated that. When he'd left for community college, it was with the understanding that he was going for good.

"I know I'm quiet," Craig said. "It's not cause of the job, that's how I am. But I really, really want to stay in Ragland. I see how people can live here and love this place for their entire lives, and all I want is to feel like it's mine, too." His explanation felt weak; he was certain he 
wasn't making sense. “And this was my last resort, aside from McDonald's. I sent out one hundred and forty-three applications before I had to ask Americorps to take me."

Jackson whistled. "Wow. So, this is a big deal for you. And if home's not an option," he trailed off, and Craig didn't offer any new information. Jackson waited, then broke into a broad grin and smacked his hand on the table. Craig jumped.

“All right then!” Jackson said. "We've got our work cut out for us, am I right?" "What?"

"You and I!" Jackson declared, all of his smiling and positivity returned. "We're going to hit the clubs! The service clubs, the social clubs, everything! We'll get you a good handful of volunteers in no time at all!"

"You really think so?" The excitement was infectious, but Craig didn't want to get riled up over false hope. "Do you know anybody who might be willing?"

"Oh.” Jackson trailed off. "I already got a lot of the people I know to sign up."

Craig cocked his head. "How many is 'a lot'?"

Jackson had personally gotten 52 of the 70 volunteers to sign up for the festival. The festival was going to be bigger than ever so he'd spent weeks campaigning, chatting up every member of the adult learning classes, the Boy Scout and Girl Scout troops, the pregnant soon-tobe mothers who learned lamaze on Wednesdays. He had scoured Ragland for volunteers.

"Of course we all signed up!” the one o'clock Résumé Workshop leader told Craig and Jackson, gesturing to her class of gruff-looking adult students. "Jackson gave us a beautiful speech about the value of community last week!" Several of the students nodded, and one guy with a skull tattoo on his forehead gave Jackson a thumbs up. The leader beamed. "It's like you said: you're always a part of your community, so you might as well give back to it!" 
"Is there anyone in your family or a friend that might want to sign up?" Craig asked.

“One step ahead of you!” exclaimed Scoutmaster Walton, pausing in his two o'clock meeting with the Assistant Scoutmasters. "We sent each of the boys home with Jackson's fliers a few weeks ago and boy howdy did we get a response! They sure were impressed by your arguments, Mr. Jackson. I already told Ms. Charlotte to expect 20 more volunteers on your behalf and on behalf of Troop 45." He gave a quick three-fingered salute. "There is nothing better than giving back to your community!"

"Can anyone sign up for a second volunteer time slot? We need some help with cleaning up," Craig pleaded.

“We can't take any extra time slots, silly, we already signed up for them all!” said Yogi Biddle, the four o'clock Lamaze instructor. "It's like Jackson said, it takes a community to raise a child, and I want to invest in my daughter through this fair. Shelly even rescheduled her ultrasound so she could attend!"

"Please, is there anyone, any way I can get even one person from the Garden Club to volunteer?" begged Craig.

"Hell no," said Philip, waving his pruning shears in the air. He was red again, but instead of the yellow Lion Club colors he wore the emerald Garden Club vest now. "And don't think you can go over my head again; I'm the President of this club."

Craig sighed. It was late in the afternoon now, and he and Jackson had been to every club and class that day without success. Now he was back to Philip, and Craig didn't feel any more persuasive than before. Without bothering with another word he turned and slumped away from the gardens and to the parking lot. Jackson chased after.

"Oh hey, come on, buddy!" Jackson said as he caught up. "I think we're getting a little 
repetitive here, am I right? Philip shuts us down, I run to catch up and give you a pep talk?

We've got to freshen up our material!" He was laughing and smiling, but Craig turned on him, a day's worth of frustration boiling up.

"Do you know what's repetitive?" he said. "Do you know what I want to change? I'd like it if you hadn't taken every single volunteer! How is it possible that you recruited half the town and Ms. Charlotte still needs volunteers?"

Jackson pulled up short. He looked genuinely hurt, but Craig wasn't feeling sympathetic right now.

“Hey man, I am sorry," Jackson said. "Ms. Charlotte pushed me hard on recruiting too. It's work I'm suited for, I didn't know it would inconvenience you." He tugged at his hair, which for once looked a little disheveled. "To tell you the truth I'm not sure how we still need volunteers either. I'll talk to her and see what's up, ok? And we can get started tomorrow, bright and early, and talk up some people.”

Thursday was as bad as Wednesday, worse even. It was destined to be tough; Thursdays occupied an uneventful spot in the Community Center's week. Craig decided that was the source of today's failures as he watched the last of the adult students drive away. No one wanted to schedule anything, especially not a club meeting, when the weekend was right around the corner. Craig had done the rounds again, but the answers came back negative each time: I already am. I would but. I signed up on Tuesday. So now he had to go to the one event unique to today, the one thing that made Craig's Thursdays graduate from inauspicious to actively painful.

"Weekly reviews!" Ms. Charlotte said, straightening the papers on her desk. She was a fastidious lady; if something couldn't be put into rows or columns then she'd pass it off to an employee. Her reviews consisted almost solely of Yes/No checkboxes. 
"So let's get right to it, shall we? The Fair. Most everything is on track, which I am very pleased to announce!"

"Wonderful!" beamed Jackson.

“Mhm," agreed Craig.

"The last of the food vendors have paid for their spots, so I was able to make the payment for the new sound equipment.” She made two check marks.

“Oh good!” Jackson enthused.

"Yes," Craig followed.

"And four more volunteers came forward from Troop $45 \ldots$..."

"No way," Craig leaned forward.

“. . each gushing about how convicting Jackson’s fliers had been.”

"Oh,” Jackson sighed. Craig said nothing.

Ms. Charlotte continued. "I'm also pleased to announce that a fifth Scout parent signed up to volunteer, apparently prompted by their child's pity on 'Jackon's sad friend.”

“Oh!" Craig said. He didn’t want to betray his excitement, but Jackson seemed set explode with energy. Craig gave in. "That's great, right?"

"Of course it is!" Jackson said, bouncing and nodding. "He's building connections with the community! Isn't that great, Ms. Charlotte?"

"It is a good start," she agreed, but she was frowning. Her pen was hovering over the checkbox reading 'Craig's Volunteers.' "Honestly I was hoping for something a little more promising. This isn't much of a start, and it is six months into the job."

Craig sank back into his seat. There was nothing left to be gained of this meeting that he could see; Ms. Charlotte had deemed him unsatisfactory. It was a pattern maintained by parents 
then teachers and now employers, with no sign of stopping.

Craig tried to turn to more pleasant thoughts, like what it would be like to have Ms.

Charlotte's job. He'd have at least a little clutter, Craig decided, and he'd write emails and move equipment and never have to speak with anyone if he didn't want to. Or he could be Jackson, someone who got praise just for existing.

“Ms. Charlotte,” Jackson said, "I think you are being a little uncharitable. Craig has done good work in every other task you've given him, and I know I have been impressed with his work ethic." He placed a hand on Craig's shoulder, which Craig shrugged off. "But moving to a new place can be very difficult, especially right out of college. Remember when I first came here a few years ago? A new town always has its own challenges."

That gave Ms. Charlotte pause, and her face softened. "Yes," she said, "but Craig hasn't had to face anything like what you're talking about. And you've done so exceptionally well, despite the few odd critics." Craig didn't know what she was talking about, but Ms. Charlotte turned her attention back to him before he could ask. "Craig," she said, "I'm measuring you against Jackson's performance, ok? If you can't even achieve a tenth of what he has by Saturday then we will have to talk." And that was that. She put her pen down, the checkbox left blank. Craig knew his hands were tied.

Jackson was quiet when they left Ms. Charlotte's office. The building was mostly empty of people now. Craig walked with him down the hallway, both stepping around fair clutter.

“So what's the plan now, boss?" Jackson asked.

Craig shrugged. "Ask around tomorrow, I guess. There are a lot more classes then." He looked back at Jackson. "What were you and Ms. Charlotte talking about?"

"Personal issues." For the first time since he'd met him Craig saw that Jackson didn't 
want to talk. They walked outside into the parking lot. "It's like I said. You move somewhere and everyone has to get used to one another. I love Ragland," Jackson said, "really I do. But it's a little slow to accept new things. You know?"

Craig didn't know and was prepared to ask, but he heard his name being called in a light woman's voice. He turned and craned his neck over the roofs of cars to spot Miss Maggie, the president of the Lion's Club, walking his way with a young girl walking beside her. As she approached, Craig realized Jackson had slipped away.

“Mister Marsden, was it?” Craig gave a quick nod. Something about this prim woman, though thin and at least sixty years old, made him anxious. She smiled. "Hello, how are you doing today? Marcy, do you know this man?”

The girl nodded, the beads in her hair clacking. "He's the water boy. I think he goes to the high school."

To her credit Miss Maggie refrained from laughing, though Craig knew he was blushing. "Mr. Marsden, you really must get out more. I would have considered overriding Philip at the meeting had I known who you were."

"I thought he was Captain Philip?" Craig said.

Miss Maggie rolled her eyes good-naturedly and reached into her purse. "Mr. Marsden, there is a Lion's Club event this Friday night. We are having line dancing here in the Center's gym and it is open to the public. Cost of entry is $\$ 10$ or a pair of glasses, whichever is easier." She retrieved a flier from her bag, a simple ad with colorful clip art of cowboys and cowgirls.

"A dance?" he said, taking the flier in his hands. "Oh I don't know, I might have other things to do .."

Miss Maggie cut him off. "There will be a lot of Senior Citizens there, Mr. Marsden, who 
don't get the chance to go to the Community Center often. I'm sure a dozen or more might be willing to sign up. Plus 'Captain' Philip won't have any say in the matter, will he?' She laughed, then noticed the child tugging at her arm. "My granddaughter insists that we must be off, Mr. Marsden. I do hope we see you tomorrow night."

The gym barely had to be decorated for the event; its old wooden bleachers and yellow lights already felt rustic, so in the end it only took a few plaid table cloths and some lively music from the new sound system to set up for the party. Craig carried in baled straw and a few loads of pumpkins, and Scoutmaster Walton brought an old barrel. That was about it.

But if the effort put into decorating was minimal, then it was more than made up for by the guests. Busloads of old, chittering women in petticoats and cowgirl boots filled the room, each sashaying and curtsying to each other in a show of how spry they still were. Those women that couldn't manage these moves were still right in the thick of it, nodding and complimenting and sharing their wisdom regarding do-si-dos. The few male residents danced and flirted away, keeping things lively. And every time songs changed, or when an old song that might have been played at their proms or weddings came on, there would come cheers and Craig saw fluttering everywhere, an excited ruffle that even those with walkers and wheelchairs couldn't resist.

Craig tried his best to match the energy, but he learned that no one demanded or expected him to. The ladies were very appreciative of his presence and seemed to ignore how he stammered when he introduced himself; mostly they'd fawn over him in his bandana and foam cowboy hat, both pressed on him by Jackson. They patted his cheek, held his arms, shouted their jokes to him and laughed whether he heard or not, but when the nostalgia came in waves they turned inwards, as if for an encore of the beautiful dancing they had done so many times so many years ago. 
Craig was comforted to see how caught up they were in their own reveries, and he felt himself relaxing. The day had been a good one; rather than advertise to entire clubs, he and Jackson positioned themselves at the entrances with clipboards and asked every individual if they wanted to volunteer. It was a rough sell— some folks really hated being accosted at the door - but by the end of the day Craig had four more volunteers. He was still waiting for the chance to tell Ms. Charlotte, but he kept finding himself in one delightfully ludicrous conversation after another.

"Emma, Emma, come here, look who I found!” One woman shouted to her friend, waving and tugging Craig through the crowd. "Look at this boy! His name is Craig and he looks like a cross between James Stewart and my old Humphrey!"

"Humphrey?” Emma squinted at Craig. "I see Jimmy, for sure. He's a stunner, 100\%. But where's the Humphrey, Bev?"

Beverly patted Craig on the shoulder. "Turn around, boy." When he complied, Emma let out an appreciative whistle.

“That's Humphrey all right!” she agreed. "My God, Bev, I thought I'd never see an ass like that again!"

Craig actually laughed, if for no other reason than because it all seemed like pleasant silliness. And it was comforting. He hadn't heard from his parents or grandparents in years, but now he had all these old people doting on him. It was a marvelous feeling.

“Are these old flirts bothering you, Mr. Marsden?” Craig recognized Miss Maggie's voice and turned with a smile, but it dropped off when he saw her dance partner.

"There's no way they're flirting with this tenderfoot, Maggie," Philip said, sneering at Craig as they continued their incongruous waltz towards him. Somehow he made his bouncy 
three-stepping fit into the Texas two-step, but it only matched up with the song every ten seconds or so. Their spinning looked frantic in comparison to the slow turns of those around him. Despite all this Miss Maggie seemed perfectly at ease.

"You underestimate him, Captain Philip," she said, bringing their dance to an end right in front of Craig. "Just as you overestimate my ability to keep up. Mr. Marsden, would you be so kind as to escort me to the drink table?"

“Oh! Sure,” Craig said, then looked at Philip, "If that's all right?"

Philip rolled his eyes. “Think I care?” He scooted closer to Emma and Beverly, wrapping an arm around each waist. "I've got my pick of the pretty ladies tonight, kid."

The two flattered old women hooted with laughter as Miss Maggie led Craig by the arm through the crowd. She smiled and greeted several people as she passed, and more than a few gave Craig the appraising looks that he'd been spared before. It made him uneasy to feel so visible, but Miss Maggie shielded him from talking to anyone on their way to the punch.

“Are you enjoying yourself this evening, Mr. Marsden?"

"Yes," Craig replied, and he poured her a drink, "I really am."

“Good. I've seen you working tonight; I think you're a better fit for this job than you realize, Mr. Marsden. Who's to say that you'll even need to leave at the end of the year?'

Craig saw Ms. Charlotte on the other side of the room, laughing and helping a man in a wheelchair allemande left. "That's nice of you. But I think my boss might be less sure."

Miss Maggie noticed where he glanced. “Oh don’t worry about Ms. Charlotte,” she said. "She manages the day-to-day, but it's Community Center Board Members like myself who make decisions on hiring and firing." Craig caught the significance. Miss Maggie smiled. "Come with me, Mr. Marsden. There are more people I want to introduce you to.” 
“Pastor Frederick Ross, Community Center Board, Vice President of Finances!” One burly man in a bolo tie introduced himself. Miss Maggie was touring Craig from group to group, introducing and praising him before whisking him away again. Everyone was very pleasant, probably on Miss Maggie's account, but the pastor acted like this moment was the highlight of his evening. "What luck, it's Craig Marsden, right? I remember when we brought you on! You graduated last year, right?"

"Yes sir." Craig took his offered hand.

“Very good, very good!” Mr. Ross said. “Didn’t I tell you, Maggie, he'd be great! Tell me boy, have you ever thought about being the Community Outreach Manager?"

There was something wrong; Craig's mind told him that so, though it took a second for him to understand why. "Wait," he said, double- and triple-checking his logic before speaking, “that's Jackson's job. Isn’t it?”

Mr. Ross looked away then, as if the conversation failed to hold his attention. Miss Maggie was at Craig's arm again. "Mr. Marsden, honey," she said, calm and collected, "The Pastor is getting a little ahead of himself. In any case," and she was smiling and leading him back into the crowd, "let's talk to the director of the retirement home, shall we? You'll need her approval if any of her people volunteer, but I'm sure I can help you butter her up. Good bye for now, Pastor!" The man waved at Craig and walked away.

Miss Maggie seemed to have no illusions about Craig's salesmanship; rather than go straight to the director they went into the hallway, where Miss Maggie had Craig rehearse what he was going to say. She lost most of her friendliness then, drilling Craig over and over with a seriousness that surprised him. But she was an effective teacher. They progressed sentence by sentence, like a director with her star performer, with strict instructions on inflection and word 
choice.

"I wanted to tell you_-" Craig recited, but Miss Maggie cut in.

"No, I wanted to tell you."

He began again. "I wanted to tell you how wonderful it is."

She nodded. "Better."

The speech was so prepared and pristine that Craig realized it had to have been written and memorized before the dance. Why had she made all this effort? Why did he need to appear outgoing for this one conversation? He didn't have time to ask about it, or even how she knew he was in such desperate need of volunteers, before he was led in the director's direction.

“Hi, I'm Craig, one of the employees here at the Ragland Community Center." Craig said, taking the stout woman's hand and shaking. "I've only got a moment, I'm supposed to go teach Miss Maggie a little Texas Two-Step, but I wanted to tell you how wonderful it is to have your residents here. They are such a gift. Are you aware that tomorrow is our annual community fair?" It came out as a long stream, and he barely paused long enough for the director to nod her head. "I was thinking how fantastic it would be if your residents came out tomorrow and joined us! We have some fliers and water bottles they could help hand out, and I know they would brighten everyone's day. Do you think that might be a possibility?"

The woman finally got to speak. "Well, I'll have to look into it." “Fantastic!” Craig cut in. "I'm not in charge of volunteers but I'm sure Miss Maggie could coordinate with you tonight. Any amount of participation would be wonderful!" And with that he was gone again, already arm in arm with Miss Maggie despite the profuse amount of sweat that had sprung up in the past thirty seconds.

"You did very well, Mr. Marsden,” she said, sounding distant. "Are you all right?" 
"Fine," Craig said. "I don’t feel sick. I guess that was okay."

Miss Maggie nodded. "Good. I want you to rest a bit, all right?" Now when she looked at him she seemed to see through him, the same look he had first received in the Lion's Club meeting. "Wait here for a bit, I'll let you know when I need you again." She patted him on the arm and was off, slipping into the crowd and disappearing.

Ms. Charlotte was on him almost immediately. "What were you doing with Maggie?"

"Talking?" Craig said. His boss had avoided him all day and evening, but now she was interrogating him in an oddly direct way. "I got four more volunteers today, Ms. Charlotte. That's five total, the number you asked for. So I did ok, right?"

"What?"

"I got a tenth of Jackson's volunteers, and in just a week. Isn't that good enough?" Craig was getting angry, but Ms. Charlotte shook her head.

“Craig, it's fine. We probably have enough help. I needed to justify you to the Board, that's all. I thought they wanted to kick you out early. But," and Ms. Charlotte seemed to be speaking to herself, "Maggie's the one who wants to cut a worker. So why is she cozying up to you?" She trailed off and left Craig where he was standing. The crowd absorbed her into the slow-moving mass.

Craig wandered among the tiring dancers. So Ms. Charlotte was pushing him around for no reason? Or she thought she needed to protect him from Miss Maggie? None of it really made sense. A song ended, then there was a slight hiss as a new one began.

I broke your heart dear; I was untrue.

And now I've lost you, what can I do?

Fate played its hand, dear, though we did try. 
Too late to worry, too blue to cry.

There were hoots and shouts in the crowd, all of them from women. Seconds later every man in the crowd was pushed to the edge, only a few resisting, and the women pressed into a tighter clump, really one massive hug, as a few sang along.

Our love is ended, you say we're through.

You found a new love that's good to you.

I hope you're happy, for I'll get by;

Too late to worry, too blue to cry.

Craig was so caught up in the watching that he didn't notice Philip until the man was upon him.

"Bunch of man-haters," he grumbled, leaning his back against the wall. "They hear one song about a man cheating and suddenly we're all villains."

Craig looked for an opportunity to escape, but Philip grabbed his elbow.

"I never cheat. Never," he said. "Worst I do is fool around. These harpies are fine with a little fun, sneaking past the orderlies at night, but if someone mentions it then six different women are mad at you, no matter whether they knew already. They're rotten, all of them."

Craig felt offended. He hardly knew the women of the residence home, but they had been nothing but sweet to him. Surely they had better taste.

"Six women? You? I don't believe it."

"What are you trying to say?" Philip said, his voice going low. He squinted his eyes and leaned toward Craig, but Craig was feeling buoyed by his successes that night.

"I'm saying that you're too cranky and rude and old to be with six women at a time," Craig said, returning Philip's glare almost perfectly. "Six women want to put up with you for that long? No way." 
Philip turned red, almost said something, then stopped. "Eh," he said, "Fair enough. It's been a few years since six was possible. Still," he said, and he elbowed Craig in the ribs, "that's a hell of a lot more women than you've had, I'd wager."

Craig laughed in spite of himself. "Yeah. Got me there."

“Oh?” Philip peered at Craig, scratching at his chin, then seemed to switch topics entirely. "Where's Jackson tonight?"

Craig shrugged. "Not here. Why?"

"Are you boys friendly?"

"No," Craig said, and all his frustrations of the past few days came back, "And why should we be? I'm a mere human and he's the God of Community Service. He's got enough friends."

Philip let out a harsh laugh, then stopped. "My God," he said.

"What?"

"You have no idea, do you?"

‘No idea about what?” Craig asked.

Philip slapped Craig's arm. "How far your head is up your own ass! Do you have any idea how hard that boy works?"

“So?” Craig was incredulous. He liked Jackson fine, but he didn't deserve all this fawning. "So? You think I'm not working hard? What do you think I'm doing every day?"

“What do you think Jackson's been doing for five years now? He's had more than his share of trouble, and at least he's not about to quit."

"I'm not quitting, I'm trying not to get fired!"

“Coulda fooled me," Philip said, shaking his head. "You got problems, I know it. Think 
nobody else has them?” He sucked his teeth. "Shit boy, I've got flat feet. I couldn't even enlist! Could hardly even dance it's so bad. You see me out there dancing?" he said, pointing to the dance floor. "That's a lifetime achievement. I oughta apply for a medal."

Craig saw that the conversation was following its own path now. He sighed and settled back against the wall. "What's so great about dancing?"

“What's so . . .?” Philip said, then cocked his head. "Didn’t you hear me? I spent my whole life learning to dance! Decades of swing and sock hops. And I was terrible. Ol' Ron Costello, he had a blue Chevy, he used to call me Flat Foot Phil. It was terrible! I was terrible. You wouldn't know it now, but it's true." Philip threw up his arms. "Hell, dancing's how I met my Rosa."

“Someone married you?" Craig said, half amused.

"Oh blow it out your ass," Philip said, but he seemed like he was on the verge of smiling. "Yeah, cause I was persistent. She was at the VE Dance and all the guys were competing to be her partner. But I impressed her by asking. She knew how terrible a dancer I was but I still asked her. So ol' Ron and the others had to watch me dance with her all night. It was amazing. She called me 'Captain."'

"Ha." Craig shook his head. He figured that was as close to endearing as he'd ever find Philip. "Congratulations then. She is a lucky lady."

Philip rolled his eyes. “'Was,' asshole. At my age it's always 'was.' The chances of making it this far are too slim.” Craig was about to apologize but Philip waved him off. "Don't worry. I'm too tough to mind. I hardly even miss her."

"Oh?"

"Not in a bad way. God no.” A bouncy trumpet piece rang out, signaling a new song. For 
all its energy the song played in a minor key with slow, drawn out guitar chords sounding like apologies playing underneath. All around the room Craig saw that the men were being drawn back into the mass of dancers, the women extending their arms and smiling to the former pariahs. More than a few moved into tight embraces as they danced. Philip sighed. "I get to dance again. That helps me. I'm still a flat-footed dunce, but I can pretend Rosa's here. She's waiting for the next dance. I'll go and dance and dance and dance until I find her again.”

Philip stepped toward the crowd, giving Craig a small nod over his shoulder as he slipped in with the dancers. The lyrics floated over the auditorium.

So long pal, it's time to say goodbye.

So long gal, drive that tear from your eye.

Now that we are parting it's hard to say goodbye,

But I'll always love you as days go drifting by.

So long pal! But do not feel so blue.

So long gal, I know you will be true.

Only keep your chin up and a smile on your face,

Though there may be others they'll never take your place.

So long pal!

As the song went on Craig saw fewer people dancing and more stopping to hug one another, old friends and best friends holding each other and rocking with closed eyes. Near the edge of the crowd Craig could see Emma and Beverly, the two flirts he'd met earlier, embracing. Emma was saying something to Beverly, who only nodded along and wiped tears from her cheeks. Craig felt tears in his own eyes before Scoutmaster Walton appeared at his side.

“Quite the dance! Wouldn't you say so, Craig?” He smiled broadly. 
Craig quickly wiped at his eyes. "Uh, yes. It's pretty great."

"A perfect way to lead in to the big fair tomorrow!" Walton continued. "You must be so excited!”

Craig shrugged. "I guess so. I've sort of been thinking of it like a deadline, not an event."

“Ah,” Scoutmaster Walton nodded. "For getting volunteers. Well," he said, giving Craig a quick nudge and a wink, "that shouldn't be a problem now that you've got twenty-six new volunteers!"

Craig looked at the Scoutmaster first in confusion, then in shock. "Twenty-six? How?"

Walton laughed. "We transferred our volunteers from Jackson! It hardly makes a difference to us, so we're glad to help you out!"

Craig felt a quick euphoria buzzing in his ears. So he had thirty-one volunteers, and Jackson twenty-six. That wasn't just success, that was victory. Absolutely lost in the feeling of sudden freedom he could only think to ask, "Did Jackson ask you to do that?"

Oddly, Scoutmaster Walton's face darkened a little. "No. No he did not. But," he said, looking Craig in the eyes, "It has recently come to my attention that Jackson's not the kind of man we want affiliated with our troop."

Craig's pleasant buzz faded. "What?"

Walton brightened then as he patted Craig on the back. "Don't worry, son. Scouts may not have a place for people like him, but we certainly have a place for you."

In the background Craig heard the song drop out, followed by the brief squeal of a microphone. At the head of the room was Miss Maggie, perched on top of a small bale and looking out over the crowd. Craig felt the blood drain from his face.

"Good evening treasured members of the community!" Miss Maggie began, her smile 
bright and unmoving. "On behalf of the Ragland Community Center I would like to thank you all for this wonderful evening of fun, friendship, and good old small-town entertainment!" She waited for the applause to die down, then continued. "Tomorrow is the Community Fair, and we would love to see you come out. Many of you met our Mr. Craig Marsden this evening; you'll be pleased to know he has personally insured that all of the residents of the Ragland Retirement Home can attend if they want! We will ask that each attendee take some time to volunteer, but," she said, holding up a long, skinny finger, "After that you get the price of your fair ticket waived!"

Excited whispers turned into applause as the crowd realized how good a deal that was. Then someone spotted Craig, and it seemed like the whole auditorium turned as one to direct their cheers towards him. It was terrible, Craig realized. This was the first he'd heard about the free tickets, and one glance at Ms. Charlotte glowering in the far corner told him that it had not been her idea. It was all Miss Maggie. She had used him, had gotten him to make a token effort so she could gather as much support to him as possible.

All to alienate Jackson, Craig realized, as a wave of little old ladies pressed in to shake his hands and hug him. He was the man of the hour, the man that they would all remember. Where was Jackson?

It was late when Craig finally snuck out of the party. He took his old Volvo and drove into a nearby neighborhood, using guesswork and his community center directory to find Jackson's house. There wasn't any parking so he had to walk a little ways from his car to the small shotgun house with the red door.

It took a minute of knocking for Jackson to answer. All the lights inside had been off, but Craig persisted until Jackson came bleary-eyed and in pajamas to the door. 
“Craig?" he said, peering through the screen door. "Hey bud, what's going on?" Jackson pushed the door open and stepped out onto the porch.

Craig avoided eye contact, instead poking at the railing around the porch. "You live nearby. I'm glad it didn't take long to get here."

"Why, is something wrong?" Jackson asked.

Craig shook his head. "No. I came from the dance."

“Oh. Okay then," Jackson said. He smiled and shook his head. "It's always good to see you, bud. Is there anything I can help you with?”

"Yes.” Craig said. "Are you gay?"

Jackson gaped, then relaxed a little. "Yeah."

“And some people like Miss Maggie have given you trouble because of it?" Jackson nodded. "Yeah."

"And that's why you're not an official Scoutmaster or anything?"

"That is the reason."

“Oh.” Craig looked away again. He knew he had misjudged Jackson. Jackson fussed with his hair, which Craig saw was still beautiful, then cleared his throat.

"It's pretty late, so I think — whoa, hey buddy." Craig was hugging him, arms wrapped around his arms and face pressed against his shoulder. They stayed that way for a second and it was the slightest bit awkward; Craig wasn't accustomed to giving or receiving hugs. But it was warm and genuine. When he pulled away, Craig could feel his face was red.

"Sorry."

"No, it's . . . it's okay." Jackson blushed too.

"I'm sorry because Miss Maggie got some of your volunteers to sign up with me." 
"It's fine."

“And I don't think the Boy Scouts are going to let you volunteer with them anymore."

"There's always the Girl Scouts."

"And I had all the old ladies write your name when they signed up to volunteer."

“That's . . . what?” Jackson asked.

Craig nodded. "Don’t worry, I already met quota."

"But ..." Jackson trailed off, then ran his hands through his hair. "How many was that?"

"Sixty-three," Craig said, then smiled. "Don't get too happy, though. Ms. Charlotte said we'd have to invent sixty tasks to keep them all busy."

Jackson stared at Craig then began to laugh. It was a light laugh, like he was still processing the information, but Craig found it contagious. Soon they were both laughing, loud and freely, with Jackson nearly doubled over and Craig leaning against the house for support. Craig wondered when he'd last gotten to laugh like this.

Finally Craig got enough control of himself to say, "Hey. I'm really sorry for being a jerk to you all week."

Jackson shook his head, wiping tears from his eyes. "It really is okay, Craig. Things are hard when you move somewhere new."

"Yeah. Yes it is." He wanted to say more, but he felt very aware of the late hour. "I guess I should go now."

“Okay,” Jackson said.

"It's late."

"Right."

“But I'll see you tomorrow, right?" Craig was backing down the steps and toward the 
sidewalk.

Jackson brightened up. “Of course, dude! It's the big Community Fair after all!” He laughed and waved. "It's been a long time coming, so we're due for some fun!"

The fair did not start out well. Twenty volunteers were setting up the tents in the dewsoaked field when the Retirement Home Buses pulled up and eighty elderly residents unloaded into the grass. Craig spent the first two hours wrangling old folks, giving out a few tasks but for the most part chatting with them and keeping them away from the heavy lifting. The old ladies recognized him so Craig mostly had fun, even if he had to occasionally retrieve Philip from harassing the food vendors.

Then, when the fair started proper, Craig turned the residents loose on the tents, and immediately the woodcarvers and jewelry makers and face-painters were engaged and smiling, showing off their wares and tying ribbons to the walkers of smiling women. Craig spotted Emma and Beverly, balloons tethered to each wrist as they ate cotton candy and toured around. He did not see Miss Maggie.

"She seemed to lose interest after she saw that the ladies were volunteering for Jackson," Ms. Charlotte said, then she smiled. "You did a lot of work for this fair, Craig. Thank you." Still not as much as Jackson had, Craig thought as he watched him juggle by the park entrance. He wasn't a good juggler; he kept losing track of the balls or dropping them on his head, but the arriving families and kids loved it. Craig watched the kids with a twinge of envy as they tugged at their parents and pointed at Jackson. Folks kept stuffing bills into the donation jar, adding far more money there than they got for the cheap admissions fee. Twice during the festival Craig was sent to empty the tip jar and lock it away; by the time the festival closed at $2 \mathrm{pm}$ and the army of Scouts, expectant mothers, adult learners and elderly residents were 
packing everything up, Craig heard that they had made twice as much money as they had last year on donations alone. Maybe more.

"Looks like the community center is better-funded than I thought," Philip said as he helped Craig fold tarps. "Didn't hurt that you sweet-talked all the lonely old ladies, did it?" Craig smiled. "It's all Jackson. He's the guy who did it."

"Suppose that's right. I'm glad Charlotte let him take charge, Maggie be damned." Craig collected the tarp against his chest. "You know about that?"

Philip nodded. “Oh sure. But don't you worry, kid. A few folks may make a fuss, but he's won the heart of the community. I guess it pays not to be a whiny, wimpy, shrinking violet, huh?" Philip stuffed the remaining tarps into a box.

“Don’t you have a caretaker?" Craig asked. "Someone who takes you to bed when you get cranky?' He'd saved that quip all day, though it didn't sound as good out loud. Philip shrugged.

“They're a little short-handed at the moment. These days I think they'd hire about anyone." Philip looked Craig up-and-down. "Never know. Now help me carry these boxes, they're too heavy for a man who was almost a veteran."

Craig gladly carried anything that need to be carried and packed away the many items that make up a community fair. He made sure each box went to the right spot and nothing went unaccounted for, coordinating and checking from the center of things. It felt good, even if it meant a lot of people were looking at him and speaking to him. He imagined his parents watching, maybe sitting on that bench beneath the tree. Look guys, he thought, I made it. 


\section{COPPERHEAD}

"What do you think about us?" she says, and it is our first discussion since summer ended. Her fingers drift over the books on my shelf, sinking and tapping one by one as she reads. I wish I'd organized better. I have the thick high school classics like A Tale of Two Cities on display, looking proud and weighty, then her finger comes along and shrinks them down to novellas. I decide to reorganize them all; I will put something collegiate, like Infinite Jest, near the front.

“I don’t know," I say. "It's been a few weeks."

"Mhm," she says, and her lips twist. I should not think about her lips. She is chaste and will not kiss anyone until her wedding day, a revelation that came early in our friendship - early enough to enhance the appeal. But later I learned of the religious sect she grew up in and left behind, how her best friend struggles to read and how she still maintains respect for her old home. She looks at my copy of Fight Club, considers, then moves on. She can read and does not kiss and has not judged me for owning Fight Club.

"I mean I did like your letters, but," she says, still no eye contact. Her finger skips DVDs, CD cases, a pencil cup, and lands on the jar filled with ethyl alcohol and a dead copperhead. Oh Lord. Lord Lord Lord. I beat its head in while my campers watched, nothing but a branch in my hand and the assurance that this was what men ought to do, and I might as well have never been praised or congratulated once in my life for the way she squints into the murky alcohol and the snake's crushed eyes. 


\section{SANDHILL CRANE FESTIVAL}

Edie had staked the entire weekend on a bunch of birds, and if that wasn't bad enough, if surprising her granddaughter with tickets for the Sandhill Crane Festival wasn't the most senile and foolish thing Edie had done in a dog's age, it turned out that none of the birds got the invite. Not one of the expected twelve thousand cranes could be seen from the deck of the rangers station, despite all the assurances from the veteran bird watchers that they had to be there somewhere. Rachel was being patient so far, thank the Lord; she and Edie diligently followed the rangers up and down the trails, nodding along like good tourists to the repeated descriptions of the birds they ought to be seeing. But Rachel was getting fidgety. Soon she'd be bored, then she'd get whiny, then her mother would hear about it and Liza would ask, "A bird festival? Really?"

“Any cranes yet?” Rachel said. She was hugging her elbows, pulling her coat tighter as she scanned the hills. "I saw more of the red birds."

"Cardinals," Edie said. How could a ten year-old not know this? She herself was no bird watcher, but still, what was that fancy private school for? Edie wanted the park rangers to do something to educate the shivering sightseers, because her Audubon pamphlet was not getting the job done. She patted the nearest ranger's shoulder.

“Excuse me, are there any better viewing spots?" Their hilltop vantage gave a good view of the meadows and fields stretching below, so it only took a glance to show they were empty.

This ranger didn't seem to mind, however. “Sorry ma'am, I've looked everywhere I can think. Can't take you too far from the bus." He turned back to the blonde beside him, but Edie tugged his jacket. 
"My granddaughter came all the way from Chicago to see the cranes," she said, overexplaining a bit. "Isn't there anywhere else?"

"She came a long way to see some birds," the blonde said, cracking up. The ranger kept smiling.

"Ma'am, I'll be loading the bus in ten, then we'll get back to the fair. Keep looking, the cranes will be somewhere."

For a minute Edie couldn't find Rachel, and she quietly panicked. Rachel was probably fine, but still, what if, what if. They were miles from the road, but there were all sorts of trees to climb and fall off of or creeks to slip in. Edie checked the ranger station, the porta potties, inside the bus - no luck. Liza would have a fit if she knew Edie had lost track of Rachel, if only for a minute. Finally, Edie got to the other side of the bus and spotted a pair of women speaking with Rachel as the girl looked through a long telescope.

“There they are!” Rachel said. "I see them, they're dancing!"

“Who’s dancing, dearie?” Edie pinched the sleeve of Rachel's jacket, feeling anxious with her granddaughter around such a nice telescope, but the Asian woman in flannel spoke before they could leave.

"We found cranes over that way! Apparently that's a mating dance." The flannel lady smiled and wrapped her arm around the waist of her willowy friend. "She knows all about them."

Bird-watching lesbians. Oddly Edie felt better now about taking Rachel to the Festival. Look, she wanted to say, even lesbians are interested! Edie had a lesbian friend once, a chattering secretary whose secret girlfriend took her to Europe on three-day weekends, and Edie thought of that as the lesbian lifestyle. The idea was likely a tad silly, but then again how many lesbians stayed in small towns? They are adventure-seekers. So Edie was extra respectful to 
these cosmopolitan women. "Thank you, ladies, for letting my granddaughter use your telescope. I hope we're not interrupting your date?"

The willowy one arched an eyebrow while the short one suppressed a giggle. Oh no, she'd said something wrong. Edie cleared her throat. "I'm sorry, we can get going. Rachel?"

The girl was glued to the telescope. "Is that how birds do it?"

Now the flannel lady laughed aloud, and Edie grabbed Rachel's hand. The ranger was calling for the bus to load.

"Thank you again!" Edie called as she walked Rachel to the bus. She heard one of the women suggestively say, "Been awhile since we've had a real date!”

Rachel pouted on the short ride back. She and Edie sat side-by-side in the plastic seats, watching through the windows as they returned to the elementary school and the festival proper. Edie wasn't sure why she was pouting; maybe because they'd left too soon or because Rachel hated the festival. But in all seriousness, what was she supposed to do? How do you keep a 10 year-old girl entertained in Birchwood, Tennessee if its only fair was a wash? Rachel needed to keep her expectations manageable, and Edie almost told her right there to check the attitude.

But chances were Rachel got her mother's stubborn streak. Liza used to throw fits if Edie so much as gave her a stern look, and she'd hate to see that kind of scene here. Liza would wail and kick, and once even pulled out her own red hair until Donald intervened. Edie had studied his process many times, the way he held Liza, the way he spoke, even the pet names he used, but could never replicate the calming effects. Too late to learn now, she thought. Best to distract.

"Did you know," Edie said, reciting from the brochure, "that cranes mate for life?" Rachel shrugged.

“They do. They'll have one or two chicks and care for them together. Mother roosts, I 
think."

Rachel nodded, seeming to come out of her funk a little bit. "How do they pick one another?"

"I'm not sure," Edie pulled out the brochure, flipped through again. "Nothing here. Didn't that woman say they dance?" If it was anything like her and Donald, the dancing had quite a lot to do with it.

"Yeah, but, like, how?" Rachel pinched her lips. "Does your bird book say?"

"No, it's about songbirds. We'll check when we get back to the fair, ok?"

Rachel took her at her word. She entered the school gym with single-minded determination, dragging Edie from one booth to the next asking if anyone knew more about the cranes. The room was packed, all the locals and artisans mingling and shopping, but Rachel quickly learned how few experts there were in the crowd. Photographers admitted to superficial knowledge; a painter explained she usually focused on waterfalls. They met a nice jeweller who had a sale on bird earrings, but Rachel walked away before Edie could politely decline. Boy Scouts, Girl Scouts, a BBQ Pitmaster, circles of high schoolers in FFA jackets and folk musicians in boots standing around space heaters, plus the unaffiliated masses somehow drawn out of their warm living rooms to stand in a school gym and look at stuffed birds. And in all this, even at the Sandhill Crane Festival, Rachel seemed to be the only one obsessed with the actual cranes.

“Don't you have a book or something?" Rachel said to one vendor. Her cross look was very much a copy of Liza’s.

"Just coloring books, little lady," the man said. "But they come with crayons if you're interested?" 
And of course Rachel was disappointed. Drat it all, thought Edie. That passion, so exciting in a girl so young, was getting crapped on. People gave her polite smiles and even told her how cute she was. Edie hated it. She wanted to grab their arms and say, "Look at my granddaughter! Thirty minutes ago she couldn't spot a cardinal from a bluebird and now she wants to study how a bird mates! How are you not thrilled by this?” This was like a moon landing for Edie, a miracle making way for the new norm, and she wished these bumpkins would form a parade in honor of bird sex and education instead of shopping for homemade baubles.

Finally Rachel's blitz was stopped by the need to find a restroom. They couldn't use the main bathroom in the women's locker room because the line was a mile long, so Edie took Rachel by the hand and led her into the school's hallways.

"I used to teach here, you know," Edie said. They were nowhere near her old classroom, but the fingerpaint art hanging on the walls felt familiar.

Rachel looked around with renewed interest. "Grandpa Donald did too, right? Before he and Mom moved?"

Inwardly Edie sighed. "Yes he did, dear."

They kept walking in uncomfortable silence. The bathrooms were much farther apart than Edie remembered, and she kept struggling for something to say about the cranes. Better luck next time? We can look it up later? That seemed to be missing the point, so she said nothing. And Rachel didn't offer any conversation either; how could she? What would a young girl even want to say to a seventy year-old woman? This walk was becoming more and more familiar, not just because Edie had taught here but because she and Liza had walked this way many times before, just as silently as they did now. Edie wasn't sure there was anything harder than speaking with someone she loved deeply but hardly knew at all. 
Outside the bathroom Rachel stopped. "You don't have to follow me in."

"I have to go as well."

Rachel pursed her lips. "No you don't. You're following me.”

Edie tried to stay patient. "Well, you are only ten."

"So?" Rachel said, indignant now. "Even Mom doesn't stalk me like this." She turned and marched into the bathroom, disappearing around the hallway corner.

She remembered this, too, Edie thought, having a kid who thought she was eternally oppressed. And Edie really did have to pee, thank you very much, so she walked right after her.

Rachel stood in the middle of the room, head cocked and a confused look on her face. Edie almost brushed past her, but then she heard the sound. Like a splashing, maybe? Something wet, but very quiet. She looked around the stark bathroom in search of the sound, but the cinderblock walls muffled every noise. Rachel seemed keyed into the noise however, and she tracked it down to the handicap stall against the back wall.

Edie heard a woman's moan, and everything snapped into clarity. Someone was screwing in there. Rachel was at the stall door now, holding the handle, but something stopped her. Edie waved her arms, and Rachel looked back in confusion and horror. "Oh my god," she mouthed, and scurried away from the door. Edie took her hand and they rushed out on tiptoes, and only when they were out the door and down the hallway did Edie wonder why they were the ones worried about being caught.

"Oh my god," Rachel said aloud now, and Edie nodded in vague agreement. Of all the places, an elementary school! She leaned against a bulletin board. Edie was scattered, a little breathless. Calm down now, she thought, you're one to judge. Don't forget you and Donald had a few rounds in bathrooms here-and-there. But that was so long ago, the kind of thing only 
someone young and foolish would do. Edie shook her head. Probably the ranger, she thought, and his blonde. She hadn't seen them in the gym, so it seemed likely. Edie checked on Rachel, who still stood gaping.

Or the lesbians! Oh god, had they caught the lesbians fooling around? She hadn't seen them either; had they left? Were there purses in the bathroom, something that said two women instead of a man and a woman? She had rushed out too quickly, had focused too much on getting Rachel out of there. And now she was not only worried about being heard but about appearing foolish in front of her granddaughter. Like the sound of two women messing around was frightening.

Rachel looked up into her eyes. "Let's go," she whispered.

Edie nodded. "Yes," she said, intentionally at her normal volume. "I'll buy you something."

Outside the school gym they got funnel cake. The concessions man was just moving his booth inside to get out of the cold, so Rachel and Edie were left alone on a bench, listening to the buzz of the gym behind them. "Should we tell anyone?" Rachel asked.

Edie dallied over the treat. This was probably meaningful for Rachel, especially if it was her first encounter with sex. Could be a foundational memory, like the lesbian secretary's story of locker room kisses or her own story of walking in on her parents late at night. She remembered her confusion, her mother's evasion; even then, hadn't Edie hated feeling lied to? How would Rachel remember her grandmother if she dodged the question now?

Edie was terrified. She could not, could never handle the big conversations when they came up; she always made a mess of things. That was true for practically every conversation with her mother, the final fights with Donald, then when she tried to get him to stay, followed by 
that one day after school when she told Liza. Edie begged Donald to break the news to her, said it was only right since he was the one leaving. But he refused, so she went. She sat Liza down and told her, over and over and in every way she could think to say, 'I love you, it's not your fault.' They had married too young, they'd grown apart, they both loved her forever and always, but things were going to be different, and she was so very sorry. Edie went to hug her daughter. Liza asked if she could live with Donald.

But for all her fear, Edie couldn't afford to avoid this conversation. She looked down at Rachel, who twiddled a piece of funnel cake in her fingers. It might be safer to stay quiet, to let this memory fade away as Rachel grew older. This wasn't the last time Rachel would encounter sex, and she'd discover her sexuality with or without Edie's input. But what Edie wanted, what she longed for so much that she'd risk their relative amiability, was for Rachel to never ever forget her. They both got so much older each year, it was unbearable. If she could claim a spot in Rachel's life, a single warm memory where her grandmother made her feel so so loved, then Edie had to take it. This little girl and her brilliant mind would keep the memory. Edie had to be gentle and fair and open-minded, because if she could do that now, it might erase a lifetime of mistakes. One person, at least, would remember her as a part of her family.

"Rachel," Edie said, and she bent so she could be eye-to-eye with her. "I'm going to tell you something very important, and I'll need you to remember it always."

Rachel looked surprised. She nodded her head. Edie saw so much of Liza and Donald in that small moment, she couldn't help but love her.

"Never in public bathrooms, okay? It's dirty. And if you must, wash your hands before and after. Whoever you're with, both of you wash your hands."

Edie held Rachel's shoulders for a long moment, then let her go. She stood up, 
straightened her blouse, and sat down beside Rachel again. That would have to do. God, she hoped that would do it. Rachel said okay, then they ate some more cake.

Rachel looked up at Edie. "So we're not going to tell anyone?"

"No," Edie said. "Live and let live."

Another crowd of festival-goers was loading onto the bus. Several of them had their own telescopes and expensive-looking binoculars, and Edie was ready to suggest another trip out to see the cranes when Rachel hopped to her feet. "Look! A flock!"

High in the sky there were gliding black dots, dipping around each other and showing quick flashes of wings.

“They're so far away," Rachel said. "Are they cranes?"

The binoculars were all loaded on the bus now. Edie stood to look after the flock, asking with her granddaughter if that was the right shape of head, the proper length of neck. And Rachel spread her arms as wide as she could, comparing wingspans and guessed yes, they probably were. 


\section{DO A GOOD TURN DAILY}

Author's Note: The following is a work of nonfiction.

\section{An Introduction to Scouting: You and Your Handbook}

My brother and I finally got to join Cub Scouts when Dad decided he would become a Den Leader; then it was all uniforms and sashes and badges and the Scout Handbook, our Holy Text, which would cover anything Dad could not. "Scouting is great," Dad told us then, and again each year as we graduated from Bear Scout to Webelos Scouts and finally true Boy Scouts, "But Tyler, it has to be done right."

“How do you do it right?” I asked. At ten years old I mostly understood Scouting as a much-needed chance to replace my friends. I'd moved to the new school across town, and the few folks that came with me remembered me as an arrogant, somewhat spazzy kid. It wasn't entirely my fault; the year before was the year my ego inflated, the year I was informed by classmates that I was really, like really smart, and I took this gift and wielded it like I was their new king. I tried to instill a new economy on the playground, where the currency was the pecans that covered the ground. I sold chocolate Kisses and haggled brutally, forcing my friends to return again and again with ever-larger piles of nuts, but only when I was done and out of chocolate did I realize pecans held no value for me. I didn't even like pecan pie, and if covering it in sugar and baking it into a pie isn't enough to fix something, what's the point? I was not so smart after all, it seemed, and I left school that day with two plastic shopping bags bulging with pecans and with fewer friends than when I had started.

So, I needed replacement friends. It seemed like a very practical trade to me, and Scouts would be the means to that end. Dad also saw Scouts as a means, but for him it was a means to 
growth, personal responsibility, the Manhood you had to earn. You may find belonging in Scouts, sure, but you would find it by earning it.

“A good Scout troop needs strong organization," Dad told me. "The adults display responsibility and forethought, then the boys learn to do the same. That's why I'm in Scouts, too; it's everybody's responsibility to help others when we can."

He was talking about my brother, Kyle. Kyle was a year younger than me, trailing me through the ranks like a shadow. Kyle's notion of Scouts was even vaguer than mine; possibly it was no different to him at nine than Sunday School or recess, with the addition of beige uniforms and flag ceremonies. But as his older brother, some small part of every meeting would invariably involve shepherding, bickering, lecturing, or avoiding Kyle. I did not enjoy that duty.

"So is regular Boy Scouts gonna be just like Cub Scouts?" I was anxious, but Dad never seemed to worry.

"I'll tell you the truth, Tyler," he said, "I think you're going to like it even better."

\section{The BSA's Commitment to Safety}

The two Scouts tried to excuse themselves, saying "Not at all, Mr. Beckett! We would never!" But Dad was having none of it. He turned to the teenaged boys and got right in their faces. "If you mess with my kid," he said, "I will beat your ass."

That was the third day of summer camp. It was only the first thing we did to get kicked out of the Scout troop.

\section{Your First Days as a Scout}

If you had asked me in the summer of 2004 what was most likely to get the Beckett 
family kicked out, I would have told you "Kyle" without having to think too hard about it. I might have found some diplomatic way to say it, for even then I was very good at dodging hard facts. I might have said, “Well he's young, so if anyone's going to mess it up it'd probably be him," or "he doesn't know how to get along with the big kids like I do." Both are examples of plausible-sounding lies that helped me avoid saying an uncomfortable truth: I didn't want Kyle in my Troop, and what's more I was all but certain his time there would be miserable.

Kyle was hyperactive and moody, as prone to throwing a fit as he was of bouncing off the walls. It was unnerving in part because he looked so much like me: skinny, with thick dark hair and a crooked grin. I have never, however, accepted this resemblance. I'd point out that he had more freckles, or green eyes instead of brown. For most people, these were minor differences.

As Kyle's brother I was an eyewitness to so many temper tantrums and erratic moments that they became commonplace, and now I have far fewer specific memories of these events than I do of peoples' reactions to them. In middle school I participated in an informal competition amongst youth group members to see who had the 'most annoying sibling;' Kyle was declared the automatic top of the list without any debate. Once, when he was a Scout Leader, my Dad was approached by one of the Scouts, a kid named Daniel. Daniel was one of Dad's favorites, particularly for his help in managing the youngest kids in the troop.

“Mr. Beckett," Daniel told him in private, "I hope you know your younger son may be the most annoying person on the earth."

Dad cocked his head. "You know, I've heard things like that before."

Daniel seemed surprised. "So you know about that?"

Dad nodded. "Yeah."

My dad, always an old hand at diplomatic responses, never seemed too hurt by folks' 
complaints. I, however, was too close in age to Kyle. Rather than get more adept at handling these confrontations through practice I became progressively less patient, to the point where I'd almost run from any confrontation related to him. As a high school student I was chased down by a classmate of mine, livid over an argument he'd had with Kyle in Spanish class.

“Today I tried to take my pencil back, cause I lent it to him for a test? Well as soon as I did he grabbed the pencil and stabbed me!" He held up his hand to show the point of lead embedded in the skin between thumb and forefinger.

"So?" I said, not looking at him as I hurried down the hallway.

"So?" My classmate repeated. "What the hell is wrong with him?"

I might have told him if I could. No one in my family ever named what was going on, though there was lots of evidence scattered through our lives. Mom would take all three kids into the pharmacy with her to get "Kyle's medicine," his daily white pills that she said helped him pay attention. And I also went along on the weekly trips to the university where Kyle got one-onone sessions with an educator. Finally I grew too curious to keep quiet, so I asked my dad what exactly made Kyle different.

"He thinks faster is all," Dad said. "And in some ways that's good and some ways that isn't. He could do really well in a fast-paced job, like a stockbroker." Dad liked this idea; he is a financial advisor, and it would have been cool to see one of the sons that looked so much like him enter a similar field.

I didn't press Dad for more information. I took the answer at face value, like it simply was a matter of speed. But I think I also understood that whatever distinguished Kyle, it was something that made Dad give serious consideration to his son's future prospects.

So forgive me if I thought taking him to sleep away camp at ten years-old was not the 
best idea.

\section{Welcoming New Scouts}

"You're going to have to make your own friends, ok?" I hefted my pack into the truck. It weighed one-third my own weight, in keeping with Scout recommendations, but it felt like carrying bricks. I did my best not to show anyone how I struggled under those thirty-odd pounds, even as I lectured Kyle. "There will be tons of boys at camp, Dad says there are like twenty different troops, so just try and find some your age."

"I want friends here!" Kyle said, pointing at the ground to indicate the church parking lot and, by extension, the Troop that was loading cars there. "Can't I hang out with you and Garrett and John?"

"No," I said, taking his pack and stuffing it into dad's truck. "Those are my friends.” It was my first time at summer camp, too, despite being in the troop for a full year. I wanted everything to be perfect, and despite my dad's encouragement, I did not have the courage to risk my few friendships by inviting Kyle to hang out.

Kyle did not care for my boundaries. "I'm going to hang out with you guys anyways. We can explore the camp together. I want to see rabbits."

I shook my head. "Hang out with Dad."

“He’s leaving Tuesday!"

"I don't care!" I said, and I slammed the car door shut. "You're ten now, figure it out yourself." 


\section{Scout Leadership}

While there are full-time Boy Scouts of America employees, the vast majority of the organization is volunteer-run. That means the adult leaders are mostly dads, with a few moms involved here and there. And while they're all working from the same handbook, allowing a bunch of volunteer fathers to make their own rules means that the BSA is run like an empire composed of smaller monarchies, or a religion with one Bible and many religious traditions. A boy's experience depended on whose dominion they fell under; understandably, this is attractive to a lot of men.

Our Dr. Aleshire, however, was something like the reluctant leader of a slightly anarchic state. The previous Scoutmaster kept the entire troop captivated with his slapstick campfire stories and his woodworking, but he had just moved away a few weeks before. So Dr. Aleshire, realizing that he did not have quite the same talent for entertainment, decided to rely on "boy leadership:" boys plan the schedules, the lessons, the trips, while the adults maintain veto power. It is a popular tactic in many troops, but it produces decidedly mixed results.

Part of our boy leadership came from Dr. Aleshire's son Chris. On my first day in the troop Chris had explained to me that he was the only source of knowledge and wisdom that I would need in the Boy Scouts of America. In fact, he would teach me a new vocabulary word every week.

“This week's word is 'Curvy,"” he said, waving his hands as if he were tracing an hourglass.

"CCurvy?"” I repeated, hands at my side.

"No, 'Curvy,"” and he repeated the hand gesture. "Be sure to show your dad and ask him what it means." 
Though oblivious to the hidden meaning, I was fairly certain doing so would get me in trouble. I decided to make a pattern of ignoring Chris. After a year of his fellowship and then his chaotic, inconsistent, and uninspiring leadership, I felt my choice was well-vindicated. But at camp he was undeniably the center of social life, and I felt desperate to earn his approval.

\section{Scout Skills}

“Damn it, Tyler, pick up your feet!" Chris told me as the hacky sack flew past me again.

“Sorry," I said, but I didn't mean it. His chunky legs barely got off the ground, and every other time he kicked the sack went off in some new direction. I remember Chris as tall and ovalshaped, with a face that seemed permanently stuck in an expression of scornful discontent. This is likely a product of biased memory, but on that day I am sure he thought very little of me and my hacky sack skills. We'd been playing off and on since our arrival on Sunday, largely because no one knew what we were supposed to do between classes. The adults got to sit in the airconditioned trading post, the older guys grew listless and irritable in the heat, and the few young Scouts were trying very hard to be liked by the big kids.

"Damn it!" Chris said again, watching the bag bounce off his shin and into a tent. "You guys really suck.”

"Shut up," I said. "Can we go to the lake?"

"Excuse you," he said, pretending to be offended. "Free swim's over, dummy."

"What do you normally do?” Garrett asked. "You've been at camp before."

"Chris usually just masturbates in his tent," Ben said from his camp chair in the shade. He was technically a camp employee — he lived there all summer, and the only reason he wasn't cleaning dishes in the cafeteria was because his troop was visiting — but he was Chris's 
classmate at school and exactly as disinterested in leadership. They looked like Laurel and Hardy, one fat and the other skinny, but they had none of the talent for humor. But they had each other's backs, and whether or not it was true at home, they were each other's best friends at camp. "But don't worry, he doesn't need any help with that."

"Go to hell," Chris said good-naturedly.

“Can you teach us something?" I asked. "Like knives?"

“Children don't get to play with knives," Ben said. "That'd be unsafe."

"Well what about fire?" Chris reached into his shirt pocket and removed a box of matches, the green-tipped kind that can light anywhere.

"It's too hot for fire," I said.

Chris ignored me. "Look at this!" And he grabbed the crotch of his pants, pulled the flap aside, and struck the match hard against his zipper, snapping it in half.

"Shit. Wait a second."

It took two more tries, but eventually Chris got the match to light. Ben was better practiced in this Scout skill, able to light one match after the other like they were made for the task.

"Quit showing off," Chris said.

“Can't help it, I'm a natural!"

Garrett was unimpressed, maybe even exasperated. At twelve this chubby kid seemed to me to be wise to the world, especially to the tough-guy acts of people like Chris and Ben. He knew these guys and liked them better than I did, but I don't think he was ever deluded about their intelligence. He wanted them to be good guys, so he took a stand. "Chris, Ben, you guys are Life Scouts, you don't have to be idiots all the time. Show us something cool or don't bother 
trying."

So they decided to make a fire bomb. This fire bomb was not an example of any technical mastery or expertise but rather the product of boyhood ingenuity, resourcefulness, and utter recklessness. Chris gathered the necessary materials while Ben made sure the campsite was clear of adult leaders, forgetting for a moment that he was technically one of our supposed boy leaders. Then they regrouped around the firepit, usually left alone during the summer months but now the site of their grand experiment.

Finally the fire was built up enough to sustain itself. Garrett had left in protest and Kyle followed him, but I was either too dumb or too morbidly fascinated to leave. Chris produced a can of Off Bug Spray and directed its stream into a plastic Coke bottle, filling the bottom third with the oily liquid. Then he twisted the Coke cap back on and handed it to Chris. "What do you think will happen?” Ben asked, apparently just now considering the possibilities.

"Who knows?" said Chris, and he dropped the bottle directly into the fire.

Everyone ran. Scouts got behind trees and tents, and some went down the hill and didn't stop, probably expecting adults to descend on us at the moment of wrongdoing. I didn't want to miss this show for the world, so I joined Chris behind a downed log and kept my head just high enough to watch the bubbling bottle.

The only person who didn't take cover was Kyle. He stood a few feet from the fire, standing on tiptoes as if he didn't have a front row seat. The bottle was highly deformed by now, its surface bubbling like pancake batter, and inside I thought I could see the bug spray boiling. Any second the bottle would burst and spray liquid fire into Kyle's face, or explode outwards and singe his legs. I wanted to tell him to move, to run away. I could not find my voice.

"It's not doing anything," Kyle said. 
Chris stood up, brushed off his pant legs. "I think he's right."

I wanted to tell him No, No he is Not right, but Chris walked up to the fire and peered down at the bottle. "If it hasn't gone off by now, it probably won't."

The bottle cap burst open, arcing the bottle four feet into the air, trailing liquid fire behind as it landed in the tall grass. Chris staggered backwards and Kyle openly gawked, and all the while various Scouts ran in circles shouting things like "Put it out!" and "Where's the water?" I remained behind the log. There was greasy smoke in the grass, and I remember wondering if we would light the whole camp on fire before Chris chased after the bottle and stomped it into smouldering garbage.

\section{A Discussion on Fire Safety}

Kyle, Chris, Ben, and I ended up receiving the lecture on fire safety. Chris and Ben were lectured because they were the oldest Scouts present and therefore responsible; Kyle because he was standing nearest the fire when the adults arrived; and myself because I was assumed Kyle's protector. The lectures were well-deserved: we were in a drought, dry dust coated every tent, tree, and camper on the mountain, and the camp's "lake" had conclusively shrunk to "pond." An uncontrolled fire would be an exceptionally bad thing, but I did not grasp the seriousness.

"I didn't have anything to do with it," I told Dr. Aleshire, then my dad. "Why am I here?"

“Then who did it?” Dad asked. I shut up. He knew who, but he wanted evidence against Ben and Chris. Dad had left his sons alone with these supposed boy leaders and had come back to his youngest son standing beside a used firebomb. What Dad wanted, perhaps rightly, was disciplinary action.

But I would not tattle, or at least not in the teens' presence. Instead, Chris maintained his 
story. "I told you, Mr. Beckett. One of the younger guys must have put it in when I wasn't

looking. We were just trying to teach your sons some fire safety."

“Dad, he's lying!” Kyle said. "Chris put the bottle in because he wanted to scare me and Ben helped him."

"You turd!" Ben said.

I almost gave a retort, but Dad put a stern hand on my shoulder. "Excuse you," Dad said to Ben, and he placed a protective hand on Kyle as well.

That was when Dr. Aleshire reached a verdict. "Whoever it was, we're going to have a special meeting tonight where we will all go over fire safety rules. There will be none of these shenanigans in our troop. And Chris, you'll serve as the troop's Fire Marshall for the rest of the week. Make sure nothing like this happens again.”

"Yes sir," Chris nodded.

Dad was not satisfied. "Stephen," he said to Dr. Aleshire, "We know what happened. I think these boys need a more serious talking-to."

"But we didn’t do anything!" Chris went wide-eyed, almost histrionic in his denial.

“Please don't treat me like I'm stupid," my dad said.

Dr. Aleshire ignored his son. 'I appreciate that, Troy, but I've got things under control. I'll be here all week to keep my eye on them. Let me resolve things."

\section{Accountability Amongst Adult Leaders}

A week later, Dad knew he set himself up. He had hoped for a few favorable witnesses at the meeting, but Aleshire was not there, nor the other adult leader that had been present when Dad threatened Chris and Ben. The leadership had record of the events, certainly: they had heard 
everything there was to be said about crazy Mr. Beckett, and now they only wanted to hear from the man himself. If Dad had delayed this meeting or been in contact with leadership beforehand he might have been in a better spot; as it was, no one seemed very interested in his account.

When I ask him now, Dad's version of events is this:

"I go back to [the campsite,] and I was packing up to leave that day. And my tent was right where the trail came into camp. And I was inside my tent, finishing up the packing, when I heard [Chris and Ben] coming back to camp together, talking about how that 'dumbass Mr. Beckett is leaving today,' and how they'll be able to do whatever they want. That really made me angry. I was leaving within fifteen or twenty minutes. I did not think things through; I did think just enough to keep me from going to go to jail, probably.

"I went and got an eighteen year-old who was with the troop as an adult, a Scout who had aged out, I don't remember his name — maybe Josh or Joshua, seemed like a nice kid. And I told him that he needed to come with me, I needed another adult with me. And I got in their faces, and I told them what I had heard them saying. 'Oh no, we never said that! We don't know what you heard, that couldn't have been us!' And I was like, 'You just walked back to camp. You walked right by my tent.' So, they're all denial, and oh no, wasn't us, couldn't be us, no no no. So I told them that if they messed with my kid anymore I was going to beat their ass. And they looked all shocked, and I was like, 'Be shocked all you want, if you mess with my kid I'm going to beat your ass.' And the other guy heard me say it, I didn't try to hide it. Better to have him there than not to have him there, but still not the right thing to say or do."

I believe this account, though that may be bias speaking. And it may be bias that shapes the way I imagine Dad being confronted by the troop leadership a week later. He acts perfectly reasonable in my mind; he had a week to consider his regrets, so no way he'd go into a meeting 
hot-headed. "I'm aware that my behavior was inappropriate," he'd say, and he'd never defend himself on that point. "But Chris and Ben had bullied Kyle nonstop for two days," he'd say. "The other adults' responses did nothing for our youngest Scouts."

And the head of this meeting, another leader who hadn't been at camp, I imagine him as firm, resolute. This is his court, and if it's a kangaroo court then all the better for him. He doesn't want the deliberation to take too long. "Troy, what is at issue are your responses to the Scouts. You threatened two of them---" Dad nods “---and hit another weeks prior."

This is a surprise accusation, and it's where Dad begins arguing. He wants to know what they are talking about, and when they tell Dad he insists on hearing testimonies from every witness. He is summarily denied.

I personally hate this part of the story. My dad, hitting a kid? That is outside my imagination. Practically speaking it's all but impossible, because he would have heard from the police if he had. Adult leaders don't hit kids then continue on as if nothing happened; they get immediate suspensions if not expulsions, and still that might be followed by police action. If my dad had assaulted a Scout, then the troop leadership was extremely irresponsible in letting him attend summer camp with the Scouts, their kids.

What Dad had done was place a firm hand on a Scout's shoulder, his way of underscoring a strong request that the Scout stop picking on the younger kids. I've received that same shoulder squeeze before, and while I can confirm it is uncomfortable, it's a stretch of the imagination to call it "violent." The squeeze was intended to be a strong admonition; Dad says that this Scout was being an ass, and based on my memories of the guy, I believe that is likely.

But by threatening Chris and Ben, Dad had made any accusations against him seem that much more probable. Under the leadership's pressure, my dad agreed to leave the troop, and he 
promised to arrange for someone else to pick up and drop off Kyle and me.

"You don't seem to understand, Mr. Beckett," the Scout Leader said. "We're not having any of you back."

\section{Breakfast: Starting Your Day Well}

A week earlier, everyone at camp gathered to eat breakfast in the cafeteria. Literally everyone, since there was no schedule or system for spreading out the troops' meals, and the line for food quickly surrounded the dining tables. Because there was so little space and so little time you only got to grab your tray with whatever food the servers put on it, pick one boxed cereal, and go get a seat wherever it was available. This rush was hardest on the younger guys like Kyle, who tended to be pickier about their food and more prone to homesickness in the mornings. I wasn't having a great time either that morning, so I wisely sat at a different table than Kyle. But I could see from the way he clung to Dad that Kyle was very aware he was leaving camp before lunch.

And his luck kept getting worse. At just the moment Dad got called over to chat with some of the other adults, Chris and Ben sat down across from Kyle. They seemed focused on their food, so Dad gave Kyle a reassuring pat before he stepped away. That was enough for Kyle, and he kept on eating his cereal until I heard Chris speak to him.

"Whatcha eating there, buddy?"

"Fruit Loops," Kyle said with a smile. It was the only thing he liked at breakfast, but they were still a treat for him.

“Oh, that's cool," Ben said. "Do you want any of our cereal? I got Raisin Bran."

"No," Kyle said, and from where I sat I could see him crinkling his nose. "That's gross 
adult cereal."

Chris laughed. "You'll always be tiny if you don't eat healthy. Come on, have a bite." He scooped a spoonful and held it out towards Kyle.

"I'd rather be tiny than fat," Kyle said.

That one was my fault. It was easiest to regain my self-assurance by making fun of Chris behind his back, and his round belly and eroding jawline were the topic of many jokes that Kyle overheard. But the difference was that I knew those jokes were meant to be told behind his back. I watched Chris's ears turn red, and all the while Kyle kept eating his cereal as if nothing had passed between them.

"That's a good point," Chris said, dumping his cereal into his bowl and licking the spoon clean. "I should just live it up."

He dunked his spoon into Kyle's bowl and scooped out a bite of Fruit Loops to swallow down. Ben immediately scooped out a bite for himself with his dirty spoon, but before he could put it in his mouth Kyle began to sob. The tears rolled down his cheeks, the only release he had for the unique stress of being lonely and away from home, and his chin wrinkled up and his lips trembled in what I saw as a very Beckett way. I felt detached, as if I knew Kyle wasn't at fault but still wanted to blame him. I didn't know how to help, and I didn't have the courage to try.

Fortunately Dad saw what happened, and he walked to Kyle and guided him by the arm to the adult table. Scoutmaster Alewine had seen it all, and he offered his bowl of Cheerios as a sign of sympathy. Kyle stayed there for the rest of breakfast, leaning into Dad's chest and eating the banana slices Dad cut for him. I never left my seat.

Chris and Ben did not escape my dad's attention for long. As everyone filed out of the dining hall he told the two of them to wait on the cafeteria's wrap-around porch. Kyle and I kept 
on going so we could make it to class; everything that followed would be retold to me in rumor in the coming days and, in small snippets, from my dad in the coming weeks.

"Ben," he said, and I imagine him speaking quietly and standing with his hands on his hips, "You've been working here for a few weeks now, right?"

"Yes, sir," Ben said, nice and innocent. Ben would have known by then he was going to be lectured.

"Then tell me, is it in your job description to make campers cry?"

What followed would have been a performance of slack-jawed shock and pantomimed denial, both Chris and Ben absolutely aghast that my dad would think them capable of any cruelty, no matter how mundane. I know this because I know what makes my dad angry, though I don't think I ever had the guts to issue my dad that kind of insult.

\section{A Long History of Scouting}

I am an Eagle Scout. I earned that rank in the spring of 2007 at the age of 15. In 2010, Kyle earned his Eagle Scout rank, which made three Beckett Eagle Scouts in our immediate family once you counted my dad. When we finished we were congratulated by the large body of men, our great cloud of witnesses, who had helped us grow in wisdom and in stature. It was our coming of age, our assumption of the family's masculine heritage: Dad's older brother Brian is an Eagle Scout, as is his cousin, Kim. And of course the man who started it all was Grandpa Jack, progenitor, engineer, Eagle Scout, and legendary presence in my childhood, even if he wasn't alive for any of it.

"You don't like your vegetable soup?" Dad asked on more than one occasion. "Be glad it's not my father's soup. For him vegetable soup was made with whatever food was about to go 
bad. This soup is heavenly by comparison."

Grandpa Jack died following a severe electrical shock while working at a power plant. Dad was eleven at the time, and used to the constant moves Jack's job required. With his death the Beckett family settled down in Georgia, and young Troy Beckett developed a reputation for a serious temper among his peers in the Clarke County education system. Nowadays he describes his younger self as an aggressive, violent young man, up until his conversion to Christianity. To my knowledge he has had no violent episodes since, with perhaps the exception of the Scout camp incident.

\section{The Importance of Parents in Scouting}

I heard very little about the altercation between my dad, Ben, and Chris. The adult leaders definitely didn't want me to hear anything, and Chris and Ben were probably a little shaken. Garrett provided the best account, which was a surprise coming from a twelve year-old.

"Your dad heard Ben and Chris coming up the road, and they were calling him a dumbass and saying they could do whatever to Kyle. Mr. Beckett cussed them out. He said he'd kick their asses if they picked on Kyle."

“Oh,” I said. Garrett was exceedingly blunt, almost bizarrely straightforward sometimes. Usually I was concerned with tact, but I'd had enough of that while trying to suss out information about the event. Instead I thanked Garrett.

He wasn't satisfied. "So you're not going to hang out with them anymore, right?" "I don’t know. Maybe. Why?"

Garrett shook his head and climbed onto his cot. "They hate both of you. I don't know why you follow them around at all." 
I sat on my cot and Garrett turned out his flashlight. In the late night's quiet I could hear some guys talking a few tents down. I tried to listen for any sound from Kyle, but he was alone in his tent now that Dad was gone. If I had been able to closely critique my thinking I would have admitted that I wanted their approval because it was denied my brother. It was pathetic, and worse than that I was being a coward. Every time they went after my brother I stood and watched, afraid of their scorn. What I wanted was their approval, but only to confirm that I was not like Kyle. I wanted to be tough, or cool, or if nothing else, normal.

But these motivations were opaque to me; I was so invested in being seen as normal that I could not possibly see myself as cowardly. Instead I chose to believe that Garrett was right, and that I was simply stupid.

\section{The Importance of Brothers in Scouting}

This is what Dad told me before he left camp: "You need to look out for Kyle, okay?"

\section{The Buddy System}

I guess I came back from class late; it's probable that I was coming from the waterfront, since the counselor always had to confirm that none of his beginning swimmers drowned in the course of the hour. Dad told me that all the waterfront staff was trained to search the bottom of the lake if they couldn't locate a missing Scout, and he had run quite a few drills there as a young camp counselor.

Again there weren't any adults in the campsite when I arrived, and I wondered if they were still counting on Chris to protect us all from fire. Our campsite was dry and dusty from that summer's drought, and the trees that stood between the rows of tents always looked pretty 
flammable to me. I walked on through, heading towards my tent in the back, when I heard Chris, Ben, and a few of the older Scouts arguing.

Kyle was standing in the middle of a little clearing, holding a box of matches in his armpit and trying to strike a match in vain against his pant's zipper. He was rubbing it back and forth with all the focus of a child filling in a coloring book, and Ben and Chris were standing very near to him, holding out their hands and demanding their matches back.

“Shut up!” Kyle said. "I'm gonna light a fire, and you can’t stop me.”

Some of the older Scouts were laughing their asses off, and probably it was very funny. Kyle had as much chance at lighting that match on his zipper as he did by staring at it, but Chris and Ben were adamant that he stop right that instant. Finally Kyle noticed his match was in ruins, and he handed the box back to Chris.

"Your matches are messed up," he said, and Ben picked him up and seated him on top of a picnic table.

"You little shit, when we tell you to do something you need to do it," Ben said.

“No I don't!' Kyle said. "I don't have to do anything you tell me, because my dad says you're not really in charge!"

The other boys laughed even more loudly at that. Garrett was not with them, and I felt like I had come upon something secretive. I did not move from my spot behind the tent.

Chris looked at his friends and decided to perform for his audience. "Do you hear that? Such disrespect!" He said, wide-eyed and mildly offended. "I think we need to teach this kid who his betters are!"

Chris walked past his friends and reached into the grass, picking up a long, thin stick and giving it a few smacks against his hand. 
"Yes, I think young Mr. Beckett here needs to learn some manners!" He waved the stick like a military conductor rousing his band, or like a circus performer with his whip. It took me a moment to realize that was exactly what Chris was suggesting: that the whip ought to be used on Kyle.

\section{Finding Your Troop}

"So we're going to have to look for a new Boy Scout troop if we want to keep going," Dad told us. We were in the kitchen at home, less than a week after camp had ended. Dad sat in a chair while we stood. "Do you want to keep going?"

Kyle nodded immediately. I don't know what it was that Kyle found appealing about Scouting. He did not, to my knowledge, make any friends at camp, and all he'd seen so far had been disappointing, frustrating, and at times, frightening. But then again I don't know why I nodded.

“Okay," Dad said, "We can find a new troop. And I'm sorry, guys," and he looked first at Kyle, then at me, "Sorry that we have to leave our old troop."

"It's okay," Kyle said, smiling. "So we're not going back?"

"No, not to that troop."

Kyle smiled even wider. "And I don't have to go to Scouts with those mean boys any more?"

Dad got at least a little reassurance from Kyle's response. He would stay involved with our Scouting careers, and our new Scoutmaster was fully aware and forgiving towards Dad for his past mistakes. There was still a lot of shame for my dad to process, as he had really believed he had put that kind of anger behind him, but it never showed itself in all our years of Scouting. 
At the moment, however, he was glad his sons seemed okay. He knew I didn't like being separated from Garrett and my other friends, but I only pouted a little. At twelve years, that's not so unusual.

\section{Respect for Others}

Chris kept whipping the stick around, taking his time as he approached Kyle. Ben held him in place, which wasn't very hard as Kyle only struggled a little bit. For the most part, he seemed transfixed by the long strip of wood.

"Boy Scouts is about respect, you see," Chris was saying. "Respect for the men in charge. I am in charge of you. You've got to learn that sometime or other."

I, too, was caught up in this performance, and at no point did it occur to me that it could all be a simple act. Chris loved putting on a show, and maybe this was exactly the kind of thing that worked with most kids. Garrett might have seen just such a display, and maybe he learned to view the older scouts with a critical, skeptical eye because of it. But to me it looked like a real threat, like my little brother was to be held down while Chris whipped him for his impudence.

Chris struck the stick once against the table, and I ran out from behind the tent and threw myself onto his shoulders, wrapping my arms around his neck and kicking at his back. The stick went flying, and Chris spun in circles.

"Blasphemy! Blasphemy!" he shouted to the howls of laughter coming from his friends. It was an improbable thing to shout, but that's exactly what he said.

I was not hurting him, nor did I really have any potential of doing so. Once I was around his neck I discovered I had no plan for how to go forward, and so I clung to his neck and tried to think. I had thought this was a moment of heroism, like the games where I forced Kyle to be a 
sidekick knight in peril for me to save, and there would be a clear line between his role and mine. And I expected to be enraged, to feel some of the self-righteous anger that my dad had when he made his dramatic exit from camp. I certainly felt like I should have been. Someone grabbed me by the waist.

"You need to let go of him," the Scout said, but I refused even as he tugged at me. As he pulled I heard Chris choke a little. I think that was the most I ever hurt him.

Kyle and I made eye contact, and he seemed as surprised as I was that we had gotten

there. I felt like a phony; maybe that was Kyle's advantage over me, his easy sincerity. My arms strained against Chris's neck.

"Blasphemy! Blasphemy!" 
VITA

Tyler Beckett

Old Dominion University

Department of English

5000 Batten Arts \& Letters

Norfolk, VA 23529

Tyler Beckett earned his Bachelor of Arts in English at Lee University in May 2014. He has work published in Guernica, Dogzplot, and matchbook. 